\title{
An early Silurian (Aeronian) cephalopod fauna from Kopet-Dagh, north-eastern Iran: including the earliest records of non-orthocerid cephalopods from the Silurian of Northern Gondwana
}

\author{
DAVID H. Evans, Mansoureh GHOBAdI POUR, LeONID E. POPOV \& HADI JAHANGIR
}

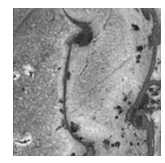

\begin{abstract}
The cephalopod fauna from the Aeronian Qarebil Limestone of north-eastern Iran comprises the first comprehensive record of early Silurian cephalopods from peri-Gondwana. Although consisting of relatively few taxa, the assemblage includes members of the orders Oncocerida, Discosorida, Barrandeocerida and Orthocerida. Coeval records of several of these taxa are from low palaeolatitude locations that include Laurentia, Siberia, Baltica and Avalonia, and are otherwise unknown from peri-Gondwana until later in the Silurian. The cephalopod assemblage occurs in cephalopod limestones that currently represent the oldest record of such limestones in the Silurian of the peri-Gondwana margin. The appearance of these cephalopods, together with the development of cephalopod limestones may be attributed to the relatively low latitudinal position of central Iran and Kopet-Dagh compared with that of the west Mediterranean sector during the Aeronian. This, combined with the continued post-glacial warming after the Hirnantian glaciation, facilitated the initiation of carbonate deposition and conditions suitable for the development of the cephalopod limestones whilst permitting the migration of cephalopod taxa, many of which were previously restricted to lower latitudes. $\bullet$ Key words: Llandovery, Aeronian, Cephalopoda, palaebiogeography, peri-Gondwana.
\end{abstract}

Evans, D.H., GHOBADI POUR, M., POPOV, L.E. \& JAHANGIR, H. 2015. An Early Silurian (Aeronian) cephalopod fauna from Kopet-Dagh, north-eastern Iran: including the earliest records of non-orthocerid cephalopods from the Silurian of Northern Gondwana. Bulletin of Geosciences 90(2), 479-507 (18 figures, 1 table). Czech Geological Survey, Prague. ISSN 1214-1119. Manuscript received October 17, 2014; accepted in revised form February 23, 2015; published online March 19, 2015; issued March 23, 2015.

David H. Evans (corresponding author), Natural England, Suite D, Unex House, Bourges Boulevard, Peterborough PE1 1NG, United Kingdom; david.evans@naturalengland.org.uk•Mansoureh Ghobadi Pour, Department of Geology, Faculty of Sciences, University of Zanjan, Zanjan, Iran and Department of Geology, National Museum of Wales, Cathays Park, Cardiff CF10 3NP, United Kingdom; mghobadipour@yahoo.co.uk • Leonid E. Popov, Department of Geology, National Museum of Wales, Cathays Park, Cardiff CF10 3NP, United Kingdom; leonid.popov@museumwales.ac.uk•Hadi Jahangir, Department of Geology, Faculty of Sciences, Ferdowsi University, Azadi Square, Mashhad 91775-1436, Iran; jahangir.hadi@gmail.com

With a few exceptions, early Palaeozoic cephalopods show a relatively complete fossil record. One of the more significant exceptions is reflected in the general dearth of cephalopod faunas in rocks of early Silurian (Rhuddanian and Aeronian) age. The paucity of cephalopod faunas during this interval is the cause of many discrepancies, as there are few clear evolutionary links between Late Ordovician and younger middle Silurian faunas. There are a relatively large number of cephalopod genera reported as common to the Ordovician and Silurian, but it is often unclear as to whether these represent evolutionary lineages or morphological convergence. In this paper, an unusual early Silurian cephalopod fauna is described from Iran.

Although Silurian strata were reported well over half a century ago from several regions of Iran, the stratigraphy and fauna of the Kopet-Dagh region remains inadequately known. Silurian sediments were first reported from the region by Brice et al. (1973, p. 179), where the Silurian and Devonian stratigraphy of the area was briefly outlined. The area was visited by the Oxford University Expedition to Iran in 1972 and extensive fossil collections were made. The Silurian brachiopods from these collections were subsequently studied and described by Cocks (1979), who also introduced the term Qarebil Limestone Formation for the Silurian deposits exposed in the vicinity of the town of Rabat-e Qarebil. The presence of the Silurian deposits in the Saluk Mountains north-east of the Gheili village and along the Pelmis valley, dated by acritarchs and chitinozoans, 
$56^{\circ} \mathrm{E}$

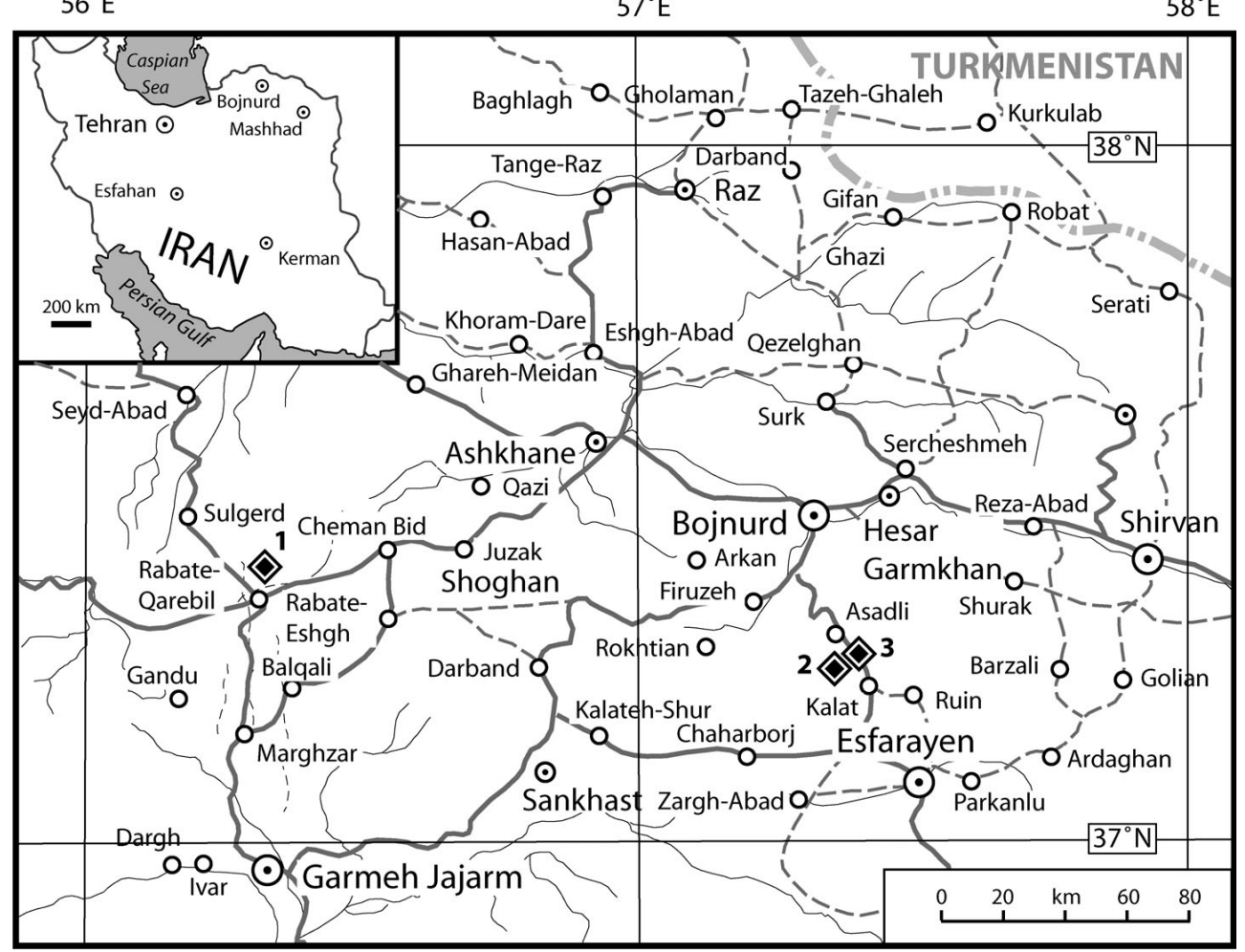

Figure 1. Map of north-eastern Iran and south-west Turkmenistan showing the locations of the sections referred to in the text: 1 - Rabat-e Qarebil; 2 - Gerdu Valley 1 and 2; 3 - Pelmis road section. was reported by Ghavidel-Syooki (2000) and GhavidelSyooki \&Vecoli (2007) who assigned these strata to the Niur Formation.

This study is based on the cephalopod collection assembled from the Silurian (Aeronian) sequences in the Saluk Mountains, south of the city of Bojnurd during several fieldwork seasons between 2009 and 2012, and the specimens collected during the 1972 Oxford University Expedition, deposited in the palaeontology collections of the Natural History Museum, United Kingdom (MHMUK). These represent the second record of an Aeronian cephalopod fauna from northern Gondwana, and the first in which the fauna is described.

To date, the only published report on Silurian cephalopods from Iran is a paper by Niko et al. (1999), who described a cephalopod fauna from Silurian sediments, probably belonging to the Shabdjereh Formation, exposed north-east of Banestan village, Kerman Province. Niko et al. (1999) listed five actinoceratid species, assigned to Armenoceras, Elrodoceras and Huroniella and one indeterminate orthocerid referred to the Proteoceratidae. The age of the fauna was referred provisionally to the late Llandoverian to early Wenlockian.

\section{Fossil localities}

The bulk of the cephalopods studied are from the eastern Saluk Mountains on the northern side of the Gerdu Valley
(Fig. 1), about $1 \mathrm{~km}$ west of the road connecting Bojnurd to Esfarayen. The geographic coordinates of the measured section are $37^{\circ} 14^{\prime} 18.4^{\prime \prime} \mathrm{N}$ and $57^{\circ} 21^{\prime} 55^{\prime \prime} \mathrm{E}$, altitude $1814 \mathrm{~m}$. Strata dip at $70^{\circ}$ north. The measured section (Fig. 2, Gerdu Valley 1 section) can be subdivided into three parts:

A lower portion comprising of more than $80 \mathrm{~m}$ of black graptolitic argillites (Fig. 2, units B1-B7) with three levels of oolitic ironstones in its middle part and graptolites of the Demirastrites triangulatus Biozone (sample B6/A) present in the uppermost $30 \mathrm{~m}$.

A middle portion consisting of about $150 \mathrm{~m}$ of bedded limestones and argillites. It is here subdivided into nine informal units (Fig. 2, B8-B16; Table 1).

The upper part of the sequence comprises of up to $250 \mathrm{~m}$ of barren sandstones and siltstones. These were assigned to the Wenlockian on the basis of the sporadic occurrence of cryptospores (Ghavidel-Syooki \& Vecoli 2007, p. 175). The Silurian strata are overlain unconformably by Devonian sediments.

The Gerdu Valley 2 section (Fig. 2) represents an isolated exposure about $100 \mathrm{~m}$ north-west of the Gerdu Valley 1 section (geographical coordinates $37^{\circ} 14^{\prime} 23^{\prime \prime} \mathrm{N}$; $57^{\circ} 21^{\prime} 51^{\prime \prime} \mathrm{E}$, altitude $1828 \mathrm{~m}$ ). Sample F-5 was taken from a level $10 \mathrm{~m}$ above the base of unit U-5; a nodular, cephalopod limestone (Fig. 3) representing the stratigraphical equivalent of unit B9 in the Gerdu Valley 1 section. The cephalopod fauna consists of Edenoceras? sp. and indeterminate straight-shelled cephalopods. Sample 

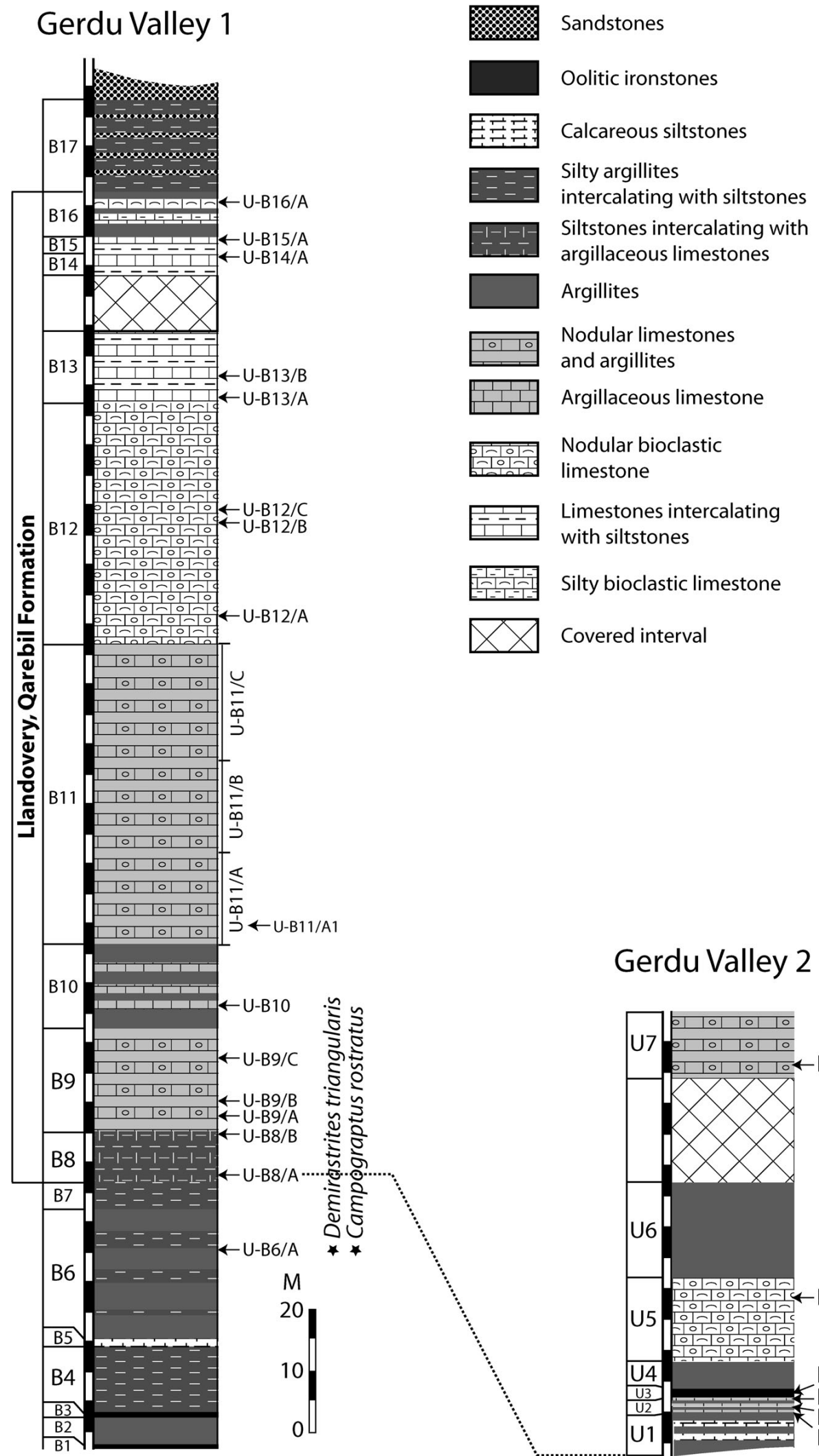

\section{Gerdu Valley 2}

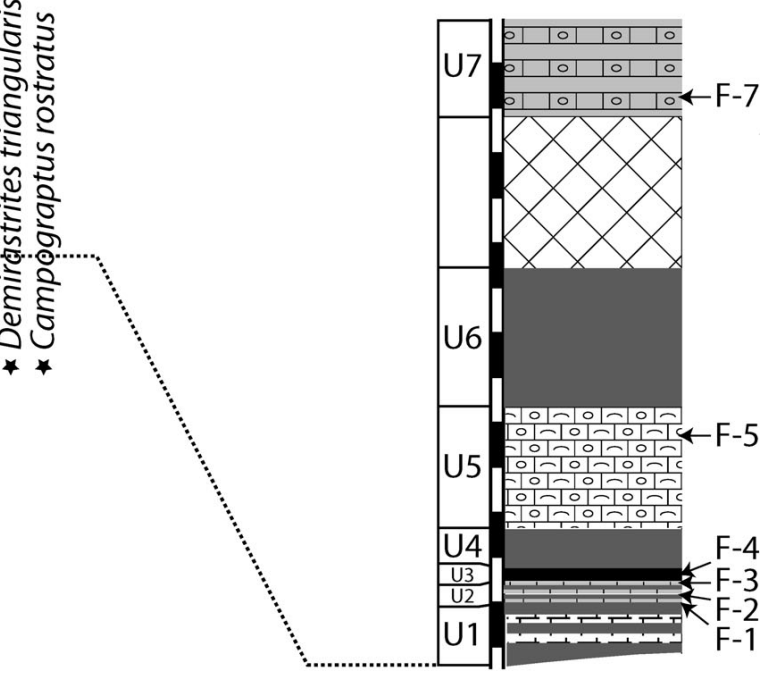

Figure 2. Stratigraphical logs of the Silurian (Llandovery) sections on the northern side of the Gerdu Valley (Saluk Mountains), showing the positions of the fossil samples discussed in the text. 
Table 1. Detailed description of part of the Pelmis 1 section between unit B8 and B16, listing the brachiopods and cephalopods recovered from each unit.

\begin{tabular}{|c|c|c|c|}
\hline \multicolumn{2}{|c|}{ Unit No.Description } & \multirow{2}{*}{$\begin{array}{c}\text { Thickness } \\
(\mathrm{m})\end{array}$} & \multirow[t]{2}{*}{ Fauna } \\
\hline B16 & $\begin{array}{l}\text { Dark grey argillites, intercalating with beds of silty limestones } \\
\text { varying from } 0.02-0.03 \mathrm{~m} \text { to } 0.10 \mathrm{~m} \text { in thickness. Upper boundary } \\
\text { placed at top of the highest limestone unit. }\end{array}$ & & \\
\hline B15 & $\begin{array}{l}\text { Dark grey silty, bioclastic limestones (individual beds } 0.03-0.06 \mathrm{~m} \\
\text { thick with uneven bedding surfaces). Includes several shell beds } \\
\text { formed mainly of disarticulated valves of Pentamerus asiaticus } \\
\text { Cocks, } 1979 \text {. }\end{array}$ & Up to 2.50 & Kionoceras sp., Protophragmoceras? sp. \\
\hline B14 & Dark grey limestones intercalated with dark grey siltstones. & 3.45 & \\
\hline \multicolumn{4}{|c|}{ Covered interval } \\
\hline B13 & $\begin{array}{l}\text { Dark grey limestones } 0.03-0.15 \mathrm{~m} \text { in thickness, intercalated with } \\
\text { dark grey siltstones } 0.01-0.05 \mathrm{~m} \text { in thickness in the lower } 3 \mathrm{~m} \text {. } \\
\text { Argillite units increasing to } 0.1-0.15 \mathrm{~m} \text { toward the upper part of the } \\
\text { unit. Some limestone beds exhibit oblique and wavy lamination. }\end{array}$ & 11.3 & $\begin{array}{l}\text { Clorinda superundata Jin \& Copper, 2000, Dolerorthis } \\
\text { plicata (J. de C. Sowerby, 1839), Eoplectodonta sp., } \\
\text { Leptaena sp., Lissatrypa sp., Segocornu procerum } \\
\text { Dürkoop, } 1970 .\end{array}$ \\
\hline B12 & Nodular, light grey to light bluish grey, bioclastic limestones. & 38.7 & $\begin{array}{l}\text { Eoplectodonta sp., Lissatrypa sp., Isorthis (Isorthis) } \\
\text { qianbeiensis (Rong \& Yang in Rong et al., 1974), } \\
\text { Stegocornu procerum. }\end{array}$ \\
\hline B11 & Light grey, nodular limestones with thin intercalations of argillites. & 48.2 & $\begin{array}{l}\text { Dalejina sp., Dolerorthis plicata, Eoplectodonta sp., } \\
\text { Isorthis (Isorthis) qianbeiensis, Leptaena sp., Lissatrypa } \\
\text { sp., Stegocornu procerum, Glyptodendron? sp. } \\
\text { Palaeodawsonocerina? sp., indet. orthocerid. }\end{array}$ \\
\hline B10 & $\begin{array}{l}\text { Dark grey argillite, with a few beds of argillaceous limestone about } \\
0.02-0.03 \mathrm{~m} \text { in thickness. }\end{array}$ & 13.7 & \\
\hline B9 & $\begin{array}{l}\text { Nodular, argillaceous limestones (individual beds from } 0.02 \text { to } \\
0.08-0.10 \mathrm{~m} \text { ) intercalated with argillites } 0.01-0.03 \mathrm{~m} \text { thick above } \\
\text { the base of the unit). }\end{array}$ & 16.45 & $\begin{array}{l}\text { Clorinda superundata, Eopholidostrophia sp., Dolerorthis } \\
\text { plicata, Leptaena sp. and Stegocornu procerum, } \\
\text { Oncoceras? sp., Protokionoceras sp., Sactoceras? sp., } \\
\text { indet. orthocerid. }\end{array}$ \\
\hline B8 & $\begin{array}{l}\text { Dark grey siltstones intercalated with argillaceous limestones, up to } \\
8.2 \mathrm{~m} \text { thick (sample B8/A taken at } 1.5 \mathrm{~m} \text { above the base of the unit } \\
\text { and sample B } 8 / \mathrm{B} \text { - at } 0.3 \mathrm{~m} \text { below the top of the unit). }\end{array}$ & 8.2 & \\
\hline
\end{tabular}

F-7 was collected $1.7 \mathrm{~m}$ above the base of unit $\mathrm{U} 7$ and consists of a light grey, nodular limestone stratigraphically equivalent to unit B11 in the Gerdu Valley 1 section. It contains Kionoceras sp., Sactoceras? sp. and indeterminate orthocerids.

In the Gerdu Valley sections, cephalopod-bearing strata first appear above black shales containing a graptolite assemblage characteristic of the Demirastrites triangulatus Biozone that includes the index species (identified by A. Suyarkova, St Petersburg; pers. comm. 2012). The biostratigraphcally important component of the brachiopod fauna from the middle part of the succession (units 8 to 16) is represented by the rhynchonellide brachiopod Stegocornu procerum Dürkoop. As recently demonstrated by Hairapetian et al. (2012), in Central Iran this species is confined to the early to mid Aeronian. Stegocornu procerum also occurs in the Qarebil Limestone Formation in the vicinity of Rabat-e Qarebil together with other characteristic taxa, including Pentamerus asiaticus Cocks. Thus the age of the brachiopod fauna from the Qarebil Limestone Formation at the Rabat-e Qarebil inlier as reassessed by Popov \& Cocks (2013) is middle Llandovery (Aeronian). Pending general revision of the Silurian lithostratigraphy of Kopet-Dagh, the stratigraphical interval from unit B8 to unit B16 of Gerdu Valley 1 section is provisionally assigned to the Qarebil Limestone Formation.

Straight-shelled cephalopods were also found in the Pelmis road section (Fig. 1), at a single locality S-13-14 $\left(37^{\circ} 14^{\prime} 29.51^{\prime \prime} \mathrm{N}, 5^{\circ} 22^{\prime} 23.74^{\prime \prime} \mathrm{E}\right)$ on the west side of the road connecting Bojnurd and Esfarayen. Although the rocks exposed along the road had previously been considered to be Ordovician in age (Ahmadzadeh-Heravi 1983), rocks from this locality contain an Aeronian brachiopod assemblage dominated by $S$. procerum, which occurs in association with less common Eoplectodonta, Katastrophomena, Leptaena, Dolerorthis, Glyptorthis, Hesperorthis, Dicoelosia, Gotatrypa and Lissatrypa, demonstrating close similarity to the fauna from the Qarebil Limestone Formation (Cocks 1979, Popov \& Cocks 2013). Cephalopods from this locality include Edenoceras? sp., Kionoceras sp., Protokionoceras sp. and indeterminate straight-shelled cephalopods.

In the Rabat-e Qarebil inlier, amongst other faunal elements, cephalopods were collected by the Oxford University Expedition (NHMUK Pl CN 141-146) from the 


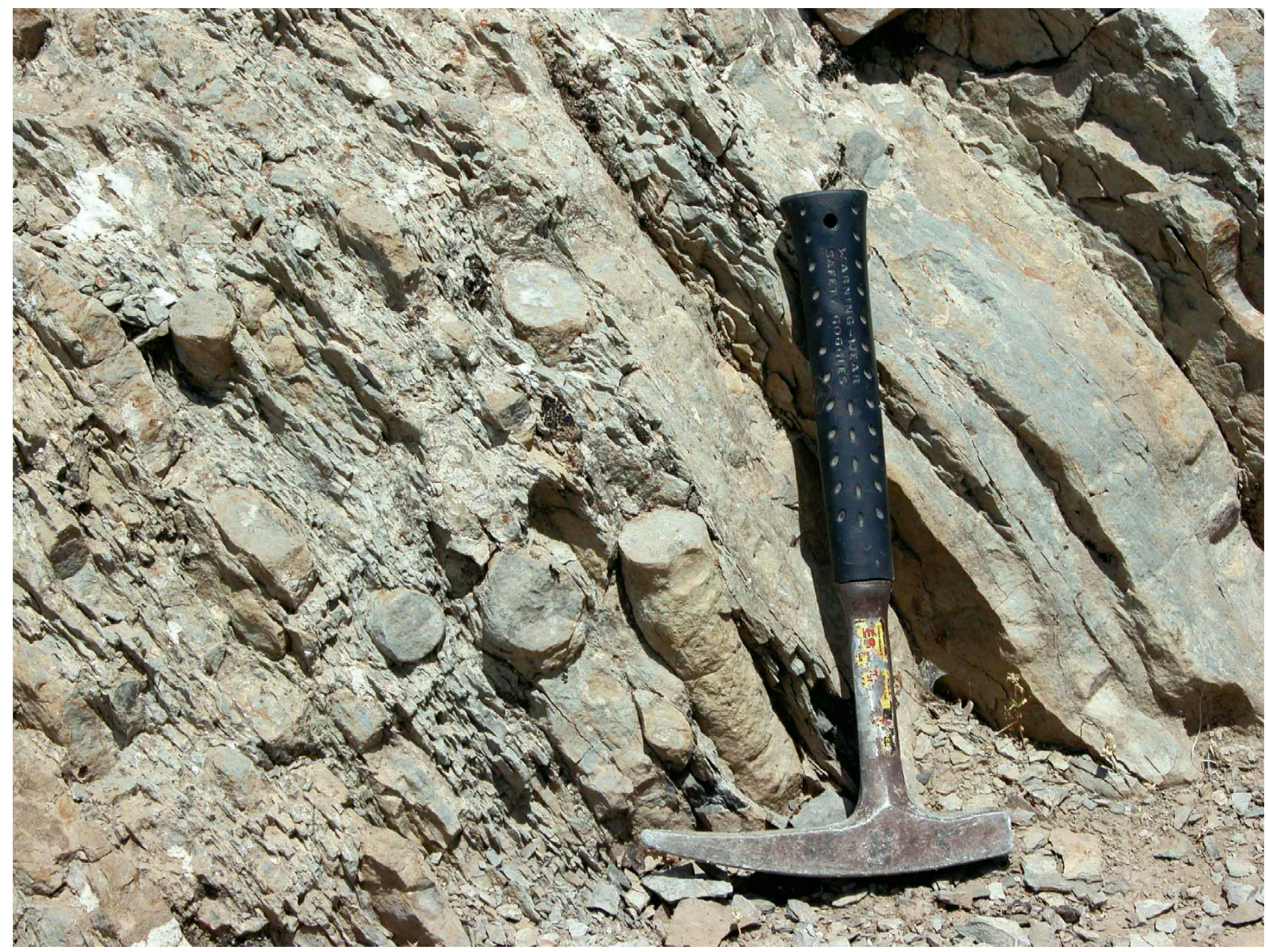

Figure 3. Detail of the cephalopod limestone of unit 5, Gerdu Valley 2 section. Showing nodular bioclastic limestones, inter-bedded with mudstones and containing many portions of worn phragmocones resting parallel to bedding, but otherwise apparently randomly oriented.

Qarebil Limestone Formation exposed about $2.5 \mathrm{~km}$ north-east of the town of Rabat-e Qarebil, situated about $60 \mathrm{~km}$ west of Bojnurd in North Khorasan Province (Fig. 1). A brief outline of the Silurian succession of the area was provided by Cocks (1979).

\section{Material and methods}

The state of preservation of this material (described further below) is such that for most specimens, any sculpture that was present on the wall of the conch has been lost, whilst the connecting rings are also generally missing, and the portions of phragmocone that have been preserved usually represent growth stages where cameral and endosiphuncular deposit are not developed. As a consequence, about half the collection can only be assigned with any confidence to the Orthocerida, and sectioning of many specimens has been necessary in the hope of discovering diagnostic internal features. The basis for the determinations of many of the specimens that have been given a more precise taxonomic assignment has relied on extrapolation from more informative specimens, particularly through plotting the relative diameter of the septal foramen against the diameter of the septal foramen divided by the distance between adjacent foraminae (Fig. 16). This gives the proportionate shape of the siphuncular segment if the connecting ring was tubular, generating a series of clusters that appear consistent for a particular taxon.

Other than the specimens from Rabat-e Qarebil (deposited at the Natural History Museum United Kingdom [NHMUK]), all the material described below is deposited in the Palaeontology collections of the National Museum of Wales (NMW).

\section{Preservation and taphonomy}

The material collected consists of thirty-one conchs that range from 8 to $110 \mathrm{~mm}$ in length and from 12 to $63 \mathrm{~mm}$ in 
diameter. No attempt has been made to document or analyse size distributions because the sample sizes are too small and it is unclear whether any of these fragments represent complete specimens taken from the exposure. All the specimens seen in situ (unit U-5; see Fig. 3) and most of the material available for study consist of internal moulds of phragmocones that in the main, lack the conch wall. Four specimens consist of body-chambers with the most adoral camerae attached, and all of these two specimens are oncocerids and the other two orthocerids.

In the few specimens where the conch wall remains, it is generally preserved as small patches largely replaced by a complex of iron oxides or hydroxides. In general, the surfaces of the phragmocones show signs of wear, and may be so worn that deep grooves are present in the vicinity of the sutures. Several specimens exhibit epizoans on the worn surfaces of the moulds. These include trepostome and cryptostome bryozoans and pelmatozoan holdfasts, which are seen to overgrow the worn sutures (NMW2014.5G.1, 31), septal surfaces (NMW2014.5G.1, 24) and apical surfaces (NMW2014.5G.11, 24). In specimen NMW2014.5G.1, several minute rhynchonellidformean brachiopods are associated with an area where the phragmocone is slightly crushed and appears to have been punctured. These may represent a cryptic association developed in a void within the phragmocone.

In the majority of specimens that were sectioned, the septa remain intact, although sometimes replaced with limonite or goethite. Only in NMW2014.5G.14, a specimen of Edenoceras? is there any evidence of the breakage of septa. This specimen shows three broken septa with the fragments set in the matrix filling the void between the intact apical and adoral septa (Fig. 5B). Connecting rings are generally missing in those specimens of a larger diameter, but may be partially or wholly intact in the siphuncular segments of smaller individuals. As with the septa, there are indications of replacement, particularly in the case of the oncocerids where the connecting rings are thickened in the vicinity of the septal necks. Endosiphuncular and cameral deposits are also partially or completely replaced, but may retain some indication of the original fabric of these structures.

Except in the case of NMW2014.5G.1, where sparite partially fills those camerae associated with damage to the conch wall, the conchs are entirely invested with sediment. In all the specimens that were sectioned the infilling sediment is extremely fine-grained and may have consisted of micrite. Peloidal textures are present in some specimens (NMW2014.5G.1, NMW2014.5G.11) and in NMW2014.5G.11 the peloids and micritic material form a set of separate filaments that appear to exhibit a flow structure through the septal foraminae. In several specimens, the matrix also appears to be invested with branching tubes, interpreted as Chondrites. Some of these are infilled with a darker micritic material (NMW2014.5G.11). The only skeletal material associated with the matrix consists of sporadic ostracod valves and pelmatozoan debris.

Some specimens may be slightly deformed, whilst the presence of slickensides on the surfaces of some individuals may reflect movement between the more competent carbonate units and less competent, more argillaceous units. Signs of pressure solution in the form stylolites, particularly around the septal foraminae, also suggest minor deformation.

The worn nature of the phragmocones, combined with the presence of epizoans encrusting worn sutures and septal surfaces, suggests that many, if not most of the assemblage is represented by portions of conch that were exhumed at least once before final burial. Prior to exhumation, the matrix within the phragmocone underwent lithification, and the exhumed conchs were subjected to erosion and corrosion, as well as encrustation by epizoans.

The general lack of body-chambers and the apical portions of the conchs may indicate that they were separated and selectively segregated before initial burial, or, through their greater fragility, were destroyed in a turbulent environment.

\section{Cephalopod limestones/concentrations}

Recent reviews and studies of cephalopod concentrations (Histon 2012a, b) indicates that the colours of cephalopod bearing units reflect broad modes of occurrence ranging from single event beds (typically black/grey) to timeaveraged accumulations (red/brown). Despite the pink to pink-brown colour of the limestones (unit U-5; Fig. 3), when sectioned most specimens are pale grey with only a hint of pink (NMW2014. 5G.31, Fig. 6K). Nevertheless, they best match the characters recognised for accumulations consisting of red/brown sediments (Histon 2012a, fig. 3) in that they are composed of multiple beds in which individual specimens may be fragmented and corroded as well as mineralised in places. Unit U-5 (Fig. 3) of the Gerdu Valley section 2 shows corroded phragmocones occurring in multiple units; both more and less argillaceous. In the exposure illustrated (Fig. 3) the conchs appear to be either randomly or bimodally distributed on the bedding planes. Histon (2012a) observed that these types of cephalopod accumulations are usually associated with transgressive system tracts within shallow environmental settings with a low sedimentation rate. The contrast between the cephalopod limestones of the Qarebil Limestone Formation and those of younger peri-Gondwana Silurian cephalopod limestones is emphasised by Štěpán Manda (pers. comm. 2015) who noted that the latter consist of dark wacke-packstones generally lacking a nodular fabric, contain frequent erosion surfaces, lack an argillaceous admix- 
ture, whist encrustations of the shells are rare, and the cephalopod assemblages are dominated by pelagic, small-shelled forms. The nodular, light-coloured argillaceous cephalopod bearing horizons of the Qarebil Limestone Formation rather resemble accumulations from tropical carbonate platforms such as those from the Hemse Beds of Gotland (Sundquist 1982).

\section{Stratigraphical and palaeobiogeographical significance}

Unlike younger Silurian cephalopod faunas, those of the Llandoverian are relatively poorly known, reflecting the worldwide collapse in cephalopod diversity during the Hirnantian (Kröger 2013, fig. 27.7) and slow recovery during the Early Silurian (e.g. Holland \& Copper 2008, fig. 2). Rhuddanian and Aeronian faunas are briefly reviewed below in order to set the context for the faunas from the Qarebil Limestone Formation.

\section{Rhuddanian faunas}

A relatively diverse Rhuddanian cephalopod assemblage consisting of nineteen genera was described from the Mojerocan Formation of the Mojero River Section of eastern Siberia by Miagkova (1967); later reviewed by Bogolepova (1995) who synonymised several of the genera proposed by Miagkova (1967). Kisselev (1998) apparently accepted Miagkova's taxa, and in listing the Silurian cephalopods of northern Siberia (Kisselev 1998, table 1), also tabulated a number of other taxa previously described by Zhuravleva (1964) as coming from Rhuddanian strata. Zhuravleva recorded these specimens from the Llandovery Series of the Kureka River. Although their precise age is unclear, the record (Miagkova 1967) of Geisonoceras kuveikense Zhuravleva from the Mojerocan Formation suggests that the material described by Zhuravleva is also Rhuddanian in age. Miagkova (1967) proposed several new genera for elements of the Mojerocan Formation, which, if accepted would imply their origination after the end-Ordovician extinction event. If Bogolepova's synonymies are accepted, more of the taxa either represent surviving Ordovician taxa or members of "waste basket genera".

Holland \& Copper (2008, fig. 2) reported five genera from the Rhuddanian, Becscie Formation of Anticosti Island, Canada. These include the stratigraphically longranging genera Polygrammoceras Foerste and Actinoceras Bronn, as well as the predominantly Silurian genera Orthocycloceras Barskov, Amphicyrtoceras Foerste and Discosorus Hall. The latter genera were also reported from underlying strata of latest Katian and Hirnantian age.

\section{Aeronian faunas}

Aeronian cephalopod faunas are more widely distributed than those of the Rhuddanian. In North America, the Gun River Formation and lower portion of the Jupiter Formation, Anticosti Island contains at least seventeen taxa belonging to the orders Oncocerida, Discosorida, Actinocerida and Orthocerida, of which $50 \%$ (5) of the genera reported (Holland \& Copper 2008) represent Ordovician survivors. They also noted the mix of Baltic and Laurentian taxa comprising these faunas.

Early Silurian cephalopod faunas described by Flower (1968) from the Severn River Limestone Formation of the Harricana River area, St James Bay Lowland, Canada are difficult to assign specific ages without clear ties between the informal lithostratigraphical units used by Flower (1968, pp. 1, 2) and the stratigraphical columns compiled by Berry \& Boucot (1970). Flower described Humeoceras, Discosorus, Megadiscosorus, Kionoceras and Narthecoceras from the lower portion of the Severn River Formation. Both Discosorus and Narthecoceras (Holland \& Copper 2008, Flower 1968) are Ordovician survivors, whilst Kionoceras is commonly used as a "waste basket" and is of uncertain significance. Other than Kionoceras, the fauna consists entirely of Laurentian taxa. Foerste (1936) described Osbornoceras? savagei and a possible phragmocerid from the underlying Nelson River Formation. Osbornoceras also occurs in the Aeronian, Brassfield Formation of Kentucky (Foerste 1936) where Foerste in Jilson (1931, p. 176) noted the presence of twenty-two cephalopod taxa. Frey (1995, p. 20) noted that the cephalopods from the Brassfield Formation were in need of revision but consisted of a mixture of Ordovician survivors, direct descendents and new Silurian taxa.

Kisselev's review (Kisselev 1998) of the cephalopods of northern Siberia indicates that the Aeronian fauna is more diverse, consisting of at least twenty-two genera representing members of the Geisonoceratidae, Michelinoceratidae, Kionoceratidae, Pseudorthoceratidae (Orthocerida); Armenoceratidae (Actinocerida); Oncoceratidae, Oocerinidae, Polyelasmoceratidae, Jovellaniidae (Oncocerida); and Mandeloceratidae (Discosorida).

The Songkanoceras assemblage, from the Aeronian Shiniulan and Xiangshmnian formations of Southern China was described by Chen et al. (1981). These formations contain Songkanoceras, Armenoceras, Armenocerina, Mixosiphonocerina, Paraproteoceras, and Malgaoceras. All except Malgaoceras and Armenoceras, are taxa that are currently regarded as endemic to Southern China (Chen et al. 1981, p. 94). This endemism persisted into the Telychian (Rong \& Chen 2003) but with substantial dilution through the presence of a range of genera known later from northwest Europe or Laurentia (Chen et al. 1981, p. 94). 


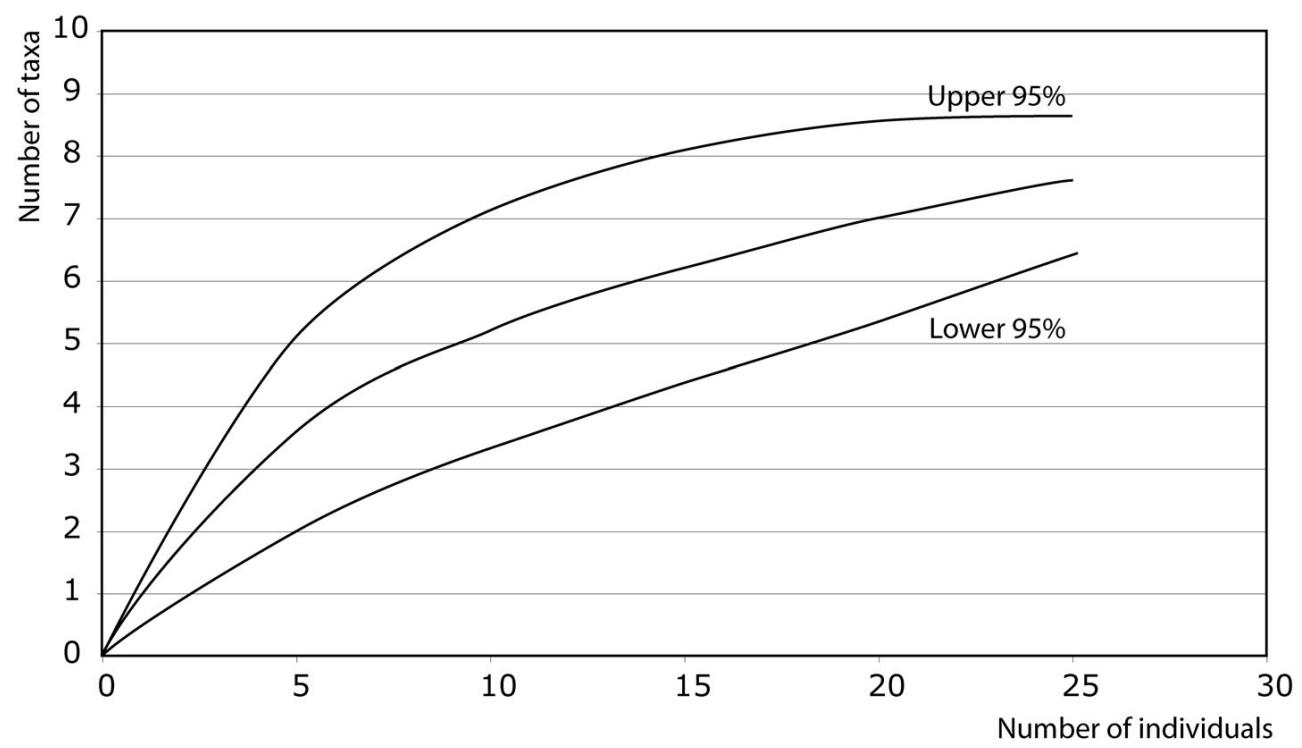

Figure 4. Rarefaction curve generated using the software package "Analytical Rarefaction 1.4" by S.M. Holland. Based upon all the cephalopods described here that were collected from the Gerdu Valley, and Pelmis sections. This is of limited value, given the limited sample size and lack of systematic controls, but suggests that there may be at least ten distinct cephalopod taxa present in the Qarebil Limestone Formation.

Holland (2014) listed Armenoceras, Gorbyoceras, Tretoceras and Trocholites from the Aeronian of Wales, although the last two taxa occur at the top and the base of the Aeronian respectively. Armenoceras, Gorbyoceras and Trocholites are Ordovician survivors, whilst Tretoceras is an endocerid closely related to Cameroceras (Evans \& Holland 1996) and also effectively represents an Ordovician survivor. The record of Aeronian cephalopods from Baltica is very poor, but may reflect a lack of study rather than a real paucity of taxa. One of the few taxa to have been described is the discosoriid, Konglungoceras norvegicum Sweet (1959) from the upper part of the Solvik Formation of the Oslo region. Despite the resemblance of the structure of the siphuncle to that of members of the Discosoridae, Sweet assigned Konglungoceras to the Cyrtogomphoceratidae on the grounds of the endogastric curvature of the conch. Given that Flower \& Teichert (1957) included the Devonian Alpenoceras in the Discosoridae on the grounds of the similarity of the morphology of the siphuncle and endosiphuncular deposits, despite its endogastric curvature, Konglungoceras may provide a link between taxa such as Discosorus and Alpenoceras. As such, Konglungoceras may be interpreted as a taxon originating during the Early Silurian.

Hitherto, with the exception of a handful of records that generally report indeterminate material e.g. Wolfart et al. 1968 (Aeronian, Conularia Sandstone Formation of Jordan), Rhuddanian and Aeronian cephalopods appear to be almost unknown from northern Gondwana. Undescribed material belonging to Dawsonoceras sp. and Protokionoceras sp. (located at the Czech Geological Survey) are known from late Aeronian volcanosedimentary rocks of Perunica (Štěpán Manda, pers. comm. 2015). Material referred to Allumettoceras Foerste, 1926, Cyrtogomphoceras Foerste, 1924, and Oxygonioceras Foerste, 1925, originated from the latest Ordovician or earliest Silurian of the Pin Formation of Spiti, northern India (Suttner \& Kröger 2006). The earliest occurrences of cephalopod limestone facies around the margins of northern Gondwana generally appear to be no older than Sheinwoodian (Gnoli 2003, fig. 4) although Kolzu et al. (2012, figs 6, 7, 11) recorded cephalopod limestones from the early Telychian of Anatolia, Turkey.

Although cephalopods have been reported from the Llandoverian portion of the Niur Formation in the Derenjal Mountains of Iran (Hairapetian et al. 2011), they occur within the Alborz Terrane, which at that time lay outboard of peri-Gondwana (Ghobadi Pour et al. 2011, Popov et al. 2009). The presence of a relatively diverse and abundant cephalopod fauna in the Qarebil Limestone Formation currently represents the earliest occurrence of a Silurian cephalopod fauna from northern Gondwana.

\section{Discussion}

The relative paucity of Rhuddanian and Aeronian cephalopod faunas, except at lower latitudes means that the affinities of the Qarebil Limestone cephalopod fauna are difficult to assess with confidence. The small number of specimens involved makes the use of rarefaction techniques suspect, but the rarefaction curve (Fig. 4) may suggest that the sample is relatively representative of the assemblage. The majority of taxa comprising the fauna described below consist of genera that represent Ordovician survivors (Kionoceras, Protokionoceras, Palaeodawsonoceras, Sactoceras and possibly Protophragmoceras). Neither Edenoceras nor Glyptodendron are represented by Ordovician species, although Edenoceras may be closely related to Oncoceras. Edenoceras, otherwise known from Siberia; 
and Glyptodendron from Laurentia, are both present in the Qarebil Limestone, but have yet to be reported from any other location. Since the Siberian and Laurentian terranes lay on the northwestern side of the Rheic Ocean (Torsvik \& Cocks 2013, figs 2.16, 2.17), the presence of these two taxa in the Qarebil Limestone, as well as those taxa appear to represent Ordovician survivors requires further comment.

Although the Late Ordovician cephalopod assemblages of high latitude Gondwana are relatively poorly known, amongst those faunas that have been studied, the occurrence of members of the Oncocerida, Discosorida, Tarphycerida and Barrandeocerida are, with the exception of a possible Diestoceras from the Late Ordovician of the Prague Basin (Marek 1999) virtually unknown. The general paucity of these particular taxa is further indicated by the cephalopod fauna of the Seyahou Formation of the Zagros Mountains, Iran, which consists entirely of members of the Orthoceratoidea (unpublished data). By contrast, representatives of the Oncocerida, Discosorida and Barrandeocerida all occur in Silurian strata (Wenlock to Přídolí) associated with the west Mediterranean sector of peri-Gondwana (Gnoli 1990, 2003; Gnoli \& Serpagli 1991; Gnoli \& Serventi 2009; Histon, 2012c; Kröger 2008; Serpagli \& Gnoli 1977) and Perunica (Manda 2007, 2008; Manda \& Turek 2009; Turek 2008). Such taxa are generally rare, but may be relatively abundant in some areas for limited intervals. Manda (2008) reported the appearance of members of the Phragmoceratidae in the Prague Basin during the Telychian, Homerian and Gorstian stages, firstly as stray immigrants, then as small endemic populations of migrants, and finally as endemic, speciating populations during the Gorstian. Whilst Manda (2008) attributed their appearance to migrations from Avalonia and Baltica, carried by the Southern Tropical Current to Perunica, he also considered that such appearances were associated with the development of cephalopod limestones formed during eustatic low-stands or through shallowing as a consequence of extrusive volcanic or tectonic uplift. In discussing the occurrence of Phragmoceras in an early Homerian horizon in the Carnic Alps, Histon (2012c) largely concurred with Manda's conclusions regarding their presence on the Gondwana margins, but also noted that the restrictions imposed by the morphology of these organisms would suggest that this part of peri-Gondwana might have been relatively close to Baltica, Avalonia and Laurentia.

The occurrence of at least three taxa in the Qarebil Limestone Formation otherwise recorded from low latitude assemblages may suggest a similar scenario to that proposed by Manda (2008). The early appearance of members of the Oncocerida, Discosorida and Barrandeocerida in the Qarebil Limestone Formation compared with that of the western Mediterranean sector of peri-Gondwana may have been the result of a relative displacement in the posi- tion of Kopet-Dagh central Iran by $5-10^{\circ}$ between the late Katian and Early Aeronian (Torsvik et al. 2012, Torsvik \& Cocks 2013), combined with continued warming after the Hirnantian glaciation (Page et al. 2007).

\section{Systematic palaeontology}

Class Cephalopoda Cuvier, 1797

Subclass Nautiloidea Agassiz, 1847

Order Oncocerida Flower, 1950 in Flower \& Kummel, 1950

Family Oncoceratidae Hyatt, 1884

\section{Genus Edenoceras Miagkova, 1967}

Type species. - Edenoceras hiliferum Miagkova, 1967, p. 19 , pl. 11, figs $1-5$, pl. 12, figs $1-4$; text-fig. 7 from the Rhuddian, Mojerokan Formation of the Mojero River, central Siberia. By original designation.

Diagnosis. - Conch strongly curved, short and tapered, exogastric. Moderately rapidly expanding to base of living-chamber. Dorsoventral cross-section oval or ovoid, slightly compressed, with tightest curvature on the ventral side of the conch. Conch surface covered with transverse ridges deflected apically over the venter. Ridges and small growth lines located between the ridges intersect with sutures at a considerable angle. Aperture laterally compressed and T-shaped with the edge of the aperture on the ventral side deflected outwards. Traces of muscle attachments are located on the bottom edge of the living chamber. Adoral camerae short and the final septum with concavity to the depth of 2.5 camerae. Sutures form weak lateral lobes with weak but distinct ventral and lateral saddles. Siphuncle narrow and oval in transverse cross-section. (Translated from Miagkova 1967, p. 19.)

Remarks. - Miagkova (1967) commented on the differences between Edenoceras and other members of the family Westonoceratidae Teichert 1933; in particular, drawing attention to the small size of the conch, the marked sinus formed by the conch sculpture over the venter, and the marginal position of the siphuncle. Bogolepova (1995) referred Edenoceras to Osbornoceras Foerste. Osbornoceras is a member of the oncocerid family Karoceratidae Teichert, 1939 (Sweet 1964b) and differs markedly from Edenoceras in possessing a strongly compressed conch that appears to have a lower rate of expansion, although Miagkova's illustrations indicate some variation in these characters. Whilst the morphology of the siphuncle in Osbornoceras is poorly known (Foerste 1936, pl. 1, fig. 2), it appears to be distinctly different from that of Edenoceras (Miagkova 1967, text-fig. 7). 
In assigning Edenoceras to the Oncocerida here, particular note is taken of the difficulties in distinguishing between oncocerid and discosorid siphuncles. The presence of relatively thick connecting rings that possess small bullette-like structures at the septal foraminae in Edenoceras (Miagkova 1967, text-fig. 7) and the specimens described below, could be taken to suggest membership of the Trimeroceratidae, recently assigned to the Discosorida by Mutvei (2012) on the grounds that the siphuncle was similar to that seen in some discosorids. Sections through the connecting ring illustrated by Mutvei (2012, fig. 2) appear to be no thicker than those seen in some non-actinosiphonate oncocerids such as those illustrated for Neumatoceras sp. (Kröger et al. 2009, fig. 5.4) and Richardsonoceras gastroscopium (Kröger et al. 2009, fig. 5.5), and suggest that in this particular case, there is little difference between Trimeroceras Hyatt, 1884 and other members of the Oncocerida that lack actinosiphonate connecting rings. Thus the morphology of the connecting rings does not exclude the assignment of this material to the Oncocerida or the Oncoceratidae.

The overall shape of the conch of Edenoceras is similar to that seen in several members of the Oncoceratidae (Oncoceras Hall, 1847; Beloitoceras Foerste, 1924; Richardsonoceras Foerste, 1932) in possessing a cyrtoconic conch with a slightly compressed cross-section and body-chamber that contracts slightly towards the aperture. However, it lacks the overtly gibbous form seen in Oncoceras and to a lesser extent in Beloitoceras but has a greater rate of conch expansion than that of Richardsonoceras. Perhaps the most obvious distinction between Edenoceras and other oncocerids is in the contracted T-shaped aperture seen in some specimens (Miagkova 1967, pl. 12, fig. 3), and in this character there is a clear similarity to Trimeroceras, but the overall shape of the conch is one of a faintly longiconic cyrtocone, as opposed to the inflated breviconic conch of Trimeroceras. Additionally, similar, if not so constricted apertures occur in the mid-Ordovician oncoceratid Maelonoceras Hyatt, 1884. Here, Edenoceras is regarded as a distinct genus related to one or other of the oncoceratid taxa noted above, representing a Middle and Upper Ordovician clade that survived the end-Ordovician extinction and persisted into the early Silurian.

\section{Edenoceras? sp.}

Figures 5A-M, 6A, B

Material. - NMW2014.5G.7 and G. 14, unit U-B11, Gerdu Valley 1 section, Kuh-e Saluk Mountains, KopetDagh, Iran. NMW2014.5G.12, upper part of unit B9/3, Gerdu Valley 1 section. NMW2014.5G.20 from unit U-5, Gerdu Valley 2 section, south of Bojnard, Kuh-e Saluk
Mountains, Kopet-Dagh, Iran. NHMUK Pl CN 145, Qarebil Limestone Formation, Rabat-e Qarebil.

Description. - NMW2014.5G.7 consists of a portion of conch $42 \mathrm{~mm}$ long consisting of an incomplete body-chamber $30 \mathrm{~mm}$ long and a short length of phragmocone $12 \mathrm{~mm}$ long. The conch is cyrtoconic, and the body-chamber decreases from a dorsoventral diameter of $28.4 \mathrm{~mm}$ at its base to $21.0 \mathrm{~mm} 25 \mathrm{~mm}$ further adorally, giving an approximate rate of contraction of $17^{\circ}$. The lateral diameters are $26 \mathrm{~mm}$ and $20.5 \mathrm{~mm}$ respectively, indicating that the conch cross-section is slightly compressed. The dorsoventral profile of the body-chamber indicates that its base, and probably also the adoral part of the phragmocone were faintly gibbous on the antisiphuncular side of the conch. Septal depth is estimated at $25 \%$ of the phragmocone diameter, and cameral depth at $16 \%$, although the only camera preserved may be approximated. The suture forms weak ventral and dorsal saddles and broad shallow lateral lobes. The centre of the siphuncle lies $8 \%$ of the way across the conch diameter from the presumed venter (the convex side of the conch) and is $1.8 \mathrm{~mm}$ in diameter ( $6 \%$ of the conch diameter) at the septal foramen. The aperture of the body-chamber is not preserved, and as the specimen consists of an internal mould, there is no trace of any shell sculpture. The base of the body-chamber shows a narrow band $4 \mathrm{~mm}$ wide that may represent an incipient septum, but together with the intact camera, the mural surfaces appear to be slightly inflated, and might indicate a pathological condition.

NMW2014.5G.12 consists of an incomplete body-chamber $34 \mathrm{~mm}$ long with part of the final camera. At its base, the body-chamber, in what is judged to be the dorsoventral plane, the diameter is $24 \mathrm{~mm}$ and the lateral diameter is $21 \mathrm{~mm}$, giving a compressed cross-section with the lateral diameter 0.88 that of the dorsoventral diameter. It is possible, however, that some of the compression may have been caused by the deformation of the shell during burial or at a later stage. Towards the apertural end of the body-chamber, the dorsoventral diameter is $17.5 \mathrm{~mm}$, and the lateral diameter $15.5 \mathrm{~mm}$, or $86 \%$ that of the dorsoventral diameter. The body-chamber decreases in diameter from the base towards the aperture at $17^{\circ}$ and its profile in a dorsoventral plane is weakly curved, and shows signs of being slightly gibbous on the side with a weak concave curvature. All that remains of the most adoral camera is a fragment of septum that is so fractured and deformed that it is not possible to estimate the depth of the camera or curvature of the septum. The septal foramen is not visible.

Although the shell is entirely missing, markings that remain on the body-chamber may indicate that a hyponomic sinus was present on the side of the conch possessing a convex curvature, suggesting that this was the venter.

The portion of phragmocone represented by 


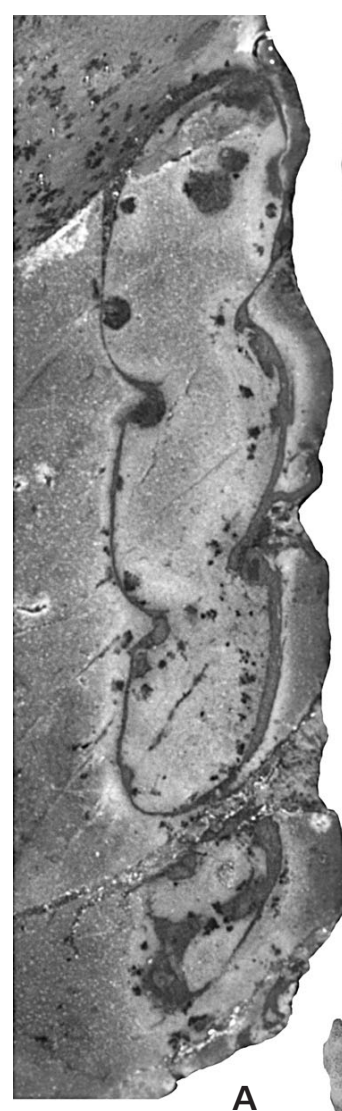

A
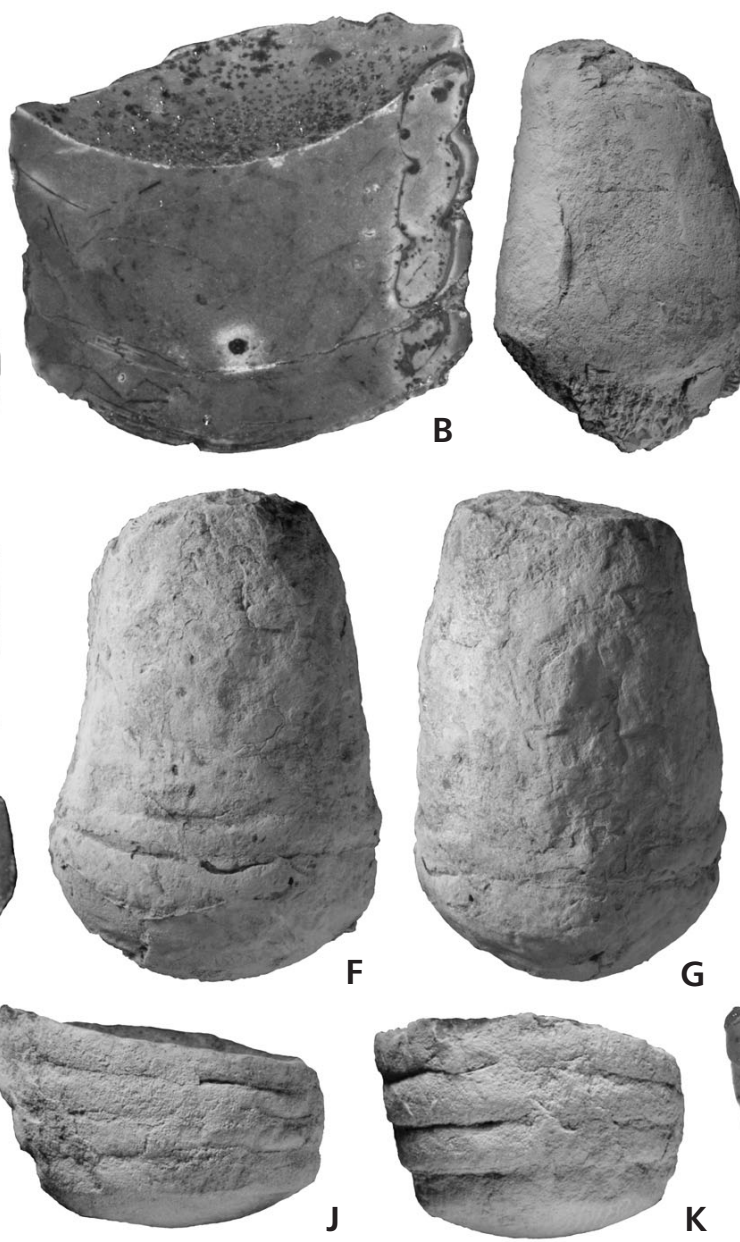

Figure 5. Cephalopods from the Qarebil Limestone Formation. Edenoceras? sp. A, B - NMW2014.5G.14, unit U-B11, Gerdu Valley 1 section. - A - detail of polished dorsoventral sagittal section showing siphuncle (see also Fig. $6 \mathrm{~B}$ ); $\times 8.0$. $\bullet \mathrm{B}-$ polished dorsoventral sagittal section, general view; $\times 2.0$. E , J-M - NMW2014.5G.20, unit U-5, Gerdu Valley 2 section. $\bullet$ E - polished dorsoventral sagittal section showing details of siphuncle (see also Fig. $6 \mathrm{~A}) ; \times 8.0 . \bullet \mathrm{L}-$ polished dorsoventral sagittal section, general view; $\times 2.0 . \bullet \mathrm{J}, \mathrm{K}, \mathrm{M}-$ lateral (venter on left), ventral and apical (venter up) views of portion of phragmocone; $\times 2.0$. $\bullet$ C, D, I - NMW2014.5G.12, upper part of unit B9/3, Gerdu Valley 1 section; lateral (venter on left?), dorsal and apical (venter up?) views of body-chamber; $\times 1.25$. $\bullet$ F-H - NMW2014.5G.7, unit U-B11, Gerdu Valley 1 section; lateral (venter on right), ventral and apical (venter up) views of body-chamber and adoral camerae; $\times 1.25$.

NMW2014.5G.14 is $27 \mathrm{~mm}$ long and $23.9 \mathrm{~mm}$ in diameter at its adoral end. The sutures show broad, shallow lobes over the lateral surfaces, and narrow, shallow saddles over the dorsal and ventral surfaces. Many of the septa have been destroyed but those that remain indicate that the septal depth was $18 \%$ that of the dorsoventral diameter, and the cameral depth $16 \%$. The siphuncle is marginal with its centre situated $2.1 \mathrm{~mm}(8.5 \%$ of the way across the conch diameter) from the phragmocone wall. The diameter of the siphuncle at the septal foraminae is $1.75 \mathrm{~mm}$ (7\% of the phragmocone diameter), increasing to $3.1 \mathrm{~mm}(13 \%)$ at the point of maximum expansion of the connecting rings. Both the septal necks and the connecting rings have been replaced by what is now probably a mixture of limonite and goethite and the structures can no longer be distinguished from each other. Nevertheless, the outline of the siphuncle segments in dorsoventral sagittal section is fusiform and barrel-shaped, with a probable wide episeptal adnation area of the connecting ring on the ventral side of the siphuncle. The zone around the septal foraminae is markedly thickened and inflated, suggesting that the connecting rings might develop into bullettes in this region.

NMW2014.5G.20 is a small piece of phragmocone $10 \mathrm{~mm}$ in length, that increases in its dorsoventral diameter from $14.6 \mathrm{~mm}$ to $16.9 \mathrm{~mm}$ in $9 \mathrm{~mm}$, giving a rate of expansion of $15^{\circ}$. In the lateral plane the phragmocone increases from $13.6 \mathrm{~mm}$ to $15.6 \mathrm{~mm}$, again indicating a weakly compressed cross-section. The depth of the septa is $10 \%$ of the dorsoventral diameter of the phragmocone, and camerae $17 \%$ that of the phragmocone diameter. The sutures are almost straight, but show very weak ventral and dorsal saddles. They are less distant on the antisiphuncular side of the 


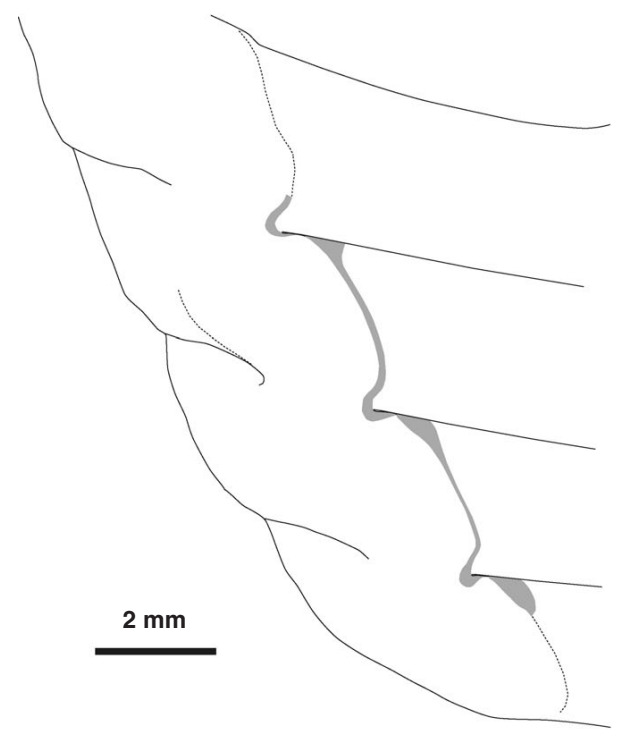

A

phragmocone, indicating that the phragmocone is cyrtoconic. The diameter of the siphuncle at the septal foramen is $1.35 \mathrm{~mm}$, or $9 \%$ of the phragmocone diameter and increases to $2.0 \mathrm{~mm}$ or $15 \%$ of the phragmocone diameter. The siphuncular segments are fusiform and barrel-shaped, and the septal necks are likely to be cyrtochoanitic and recumbent (Figs 5A, B, E, 6A, B). The connecting rings are dark and thickened over the septal foramen to form small bullette-like structures on the apical face of the septal neck. Where the connecting ring is better-preserved, there are indications that it may have been thickened throughout the length of the segment.

NMHUK Pl CN 145 is a portion of phragmocone $11 \mathrm{~mm}$ long and $16.2 \mathrm{~mm}$ by $14.86 \mathrm{~mm}$ in diameter with an apical angle of $7.6^{\circ}$. Cameral depth is $14 \%$ of the dorsoventral diameter of the phragmocone and the diameter of the septal foramen $7 \%$. The siphuncle is marginal and its centre is situated $8.5 \%$ of the way across the diameter of the siphuncle.

Remarks. - Given the fragmentary nature of these specimens, combined with the fact that they originate from slightly different horizons, there may be some doubt as to whether they all belong to the same taxon. Features common to two or more of the specimens include the possession of a compressed cross-section, exogastric curvature of the conch, a marginal siphuncle, shallow camerae, and a body-chamber that appears to be faintly gibbous on the antisiphuncular side of its base and most probably extends on to the adoral part of the phragmocone.

As interpreted here, the shape of the conch in these specimens, also rules out assignment to the Trimeroceratidae Hyatt, 1900 or Hemiphragmoceratidae Foerste, 1926. Of previously described Early Silurian cephalopod
Figure 6. Interpretation of cut and polished dorsoventral sagittal sections of Edenoceras? sp. • A - NMW2014.5G20 (see Fig. 5E). • B - NMW2014.5G14 (see Fig. 5A). Both show the development of "bullettes" at the septal foraminae.
B

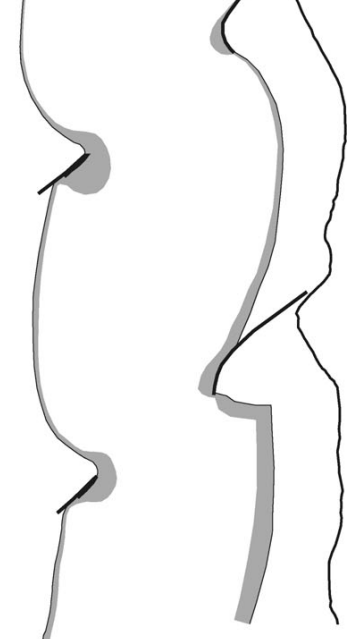

taxa, the overall form of the conch appears most similar to that of Edenoceras, however, it differs in the faint gibbosity of the base of the body-chamber, although this may be present in at least one of the specimens assigned to Edenoceras (Miagkova 1967, pl. 11, figs 3a, 4a, pl. 12, figs 1a, 3a).

Order Discosorida Flower, 1950 in Flower \& Kummel, 1950

Family Protophragmoceratidae nov.

Diagnosis. - Weakly to strongly curved endogastric cyrtocones; weakly expanding, or faintly contracting body-chamber with weak sinus on the concave side of the conch. Moderately to weakly compressed cross-section. Relatively shallow camerae. Siphuncle marginal to submarginal. Septal necks cyrtochoanitic and recumbent. Connecting rings thickened, with bullettes developed at the septal foraminae.

Remarks. - Manda (2007) excluded all genera other than Phragmoceras Broderip in Sowerby in Murchison, 1834 and Tubiferoceras Hedström, 1917 from the Phragmoceratidae and diagnosed the Phragmoceratidae on the presence of a contracted and highly modified aperture. Other genera previously assigned to the Phragmoceratidae by Flower \& Teichert (1957) were transferred to the Oncocerida, or other discosorid families. Flower \& Teichert noted the probable close relationship of Protophragmoceras Hyatt, 1900 and Endoplectoceras Foerste, 1924 to Strandoceras Flower 1946 as well as to Phragmoceras. Dzik (1984) regarded Strandoceras strandi Sweet from the Cephalopod Shale Member of the Nes-Hamar district of the Oslo region 
[N. gracils biozone, early Sandbian (Hansen 2009, fig. 5)] as the earliest representative of the Discosorida. However he regarded Strandoceras as a junior synonym of Protophragmoceras (Dzik 1984); discussed further below. He considered Ulrichoceras Foerste, 1928, taken as the oldest member of the Cyrtogomphoceratidae by Flower \& Teichert (1957), to be closely related to Ruedmannoceras Flower, 1940. Since Dzik interpreted Ruedmannoceras as a member of the Orthoceratoidea, it would follow that Ulrichoceras also belongs to the subclass. Whatever the position of Ruedmannoceras, Ulrichoceras possesses a siphuncle with thick connecting rings and well-developed bullettes (see Flower \& Teichert 1957, pl. 9, fig. 3). Since the only known species of Ulrichoceras was recorded from the Plattville Limestone and is therefore slightly younger than S. strandi, it is possible that Strandoceras could have given rise to Ulrichoceras. Ulrichoceras may have given rise to Cyrtogomphoceras Foerste, 1924 and Landeroceras Foerste, 1935, both of which possess markedly gibbous conchs and body-chambers with contracted apertures that differ markedly from Protophragmoceras and allied forms including Kieroceras Strand, 1934, Lyckholmoceras Teichert, 1930 and possibly, Parryoceras Sweet \& Miller, 1957.

Given the similarity of the internal morphology of taxa such as Protophragmoceras and Phragmoceras, in practice, members of the two families may only be distinguished with confidence on the basis of the form of the body-chamber. Without the body-chamber, distinction may still be possible based on the generally higher rate of conch expansion in the Phragmoceratidae, and the higher angles that the septa make with the striae of the growth increments on the convex side of the shell.

Constituent genera, occurrence and ranges. - Protophragmoceras Hyatt, 1900 [? = Strandoceras Flower, 1946]; Ordovician (Sandbian and Katian) of Scandinavia, England and Wales; Silurian, Telychian of Scotland, Wenlockian and early Ludlovian of China, Czech Republic, Sardinia and the United States. Endoplectoceras Foerste, 1926; Wenlockian of the Czech Republic. Kieroceras Strand, 1934; Ordovician (Katian) of Scandinavia. Lyckholmoceras Teichert, 1930; Ordovician (Katian) of Scandinavia. Parryoceras(?) Sweet \& Miller, 1957; Ordovician (Katian) of Baffin Island, Arctic Canada. Sthenoceras Flower, 1957 in Flower \& Teichert, 1957; Silurian (Wenlockian) of the Czech Republic.

\section{Genus Protophragmoceras Hyatt, 1900 in Zittel (1900) $(?=$ Strandoceras Flower, 1946)}

Type species. - Cyrtoceras murchisoni Barrande, 1866. From the Wenlock Series of the Czech Republic. By original designation.
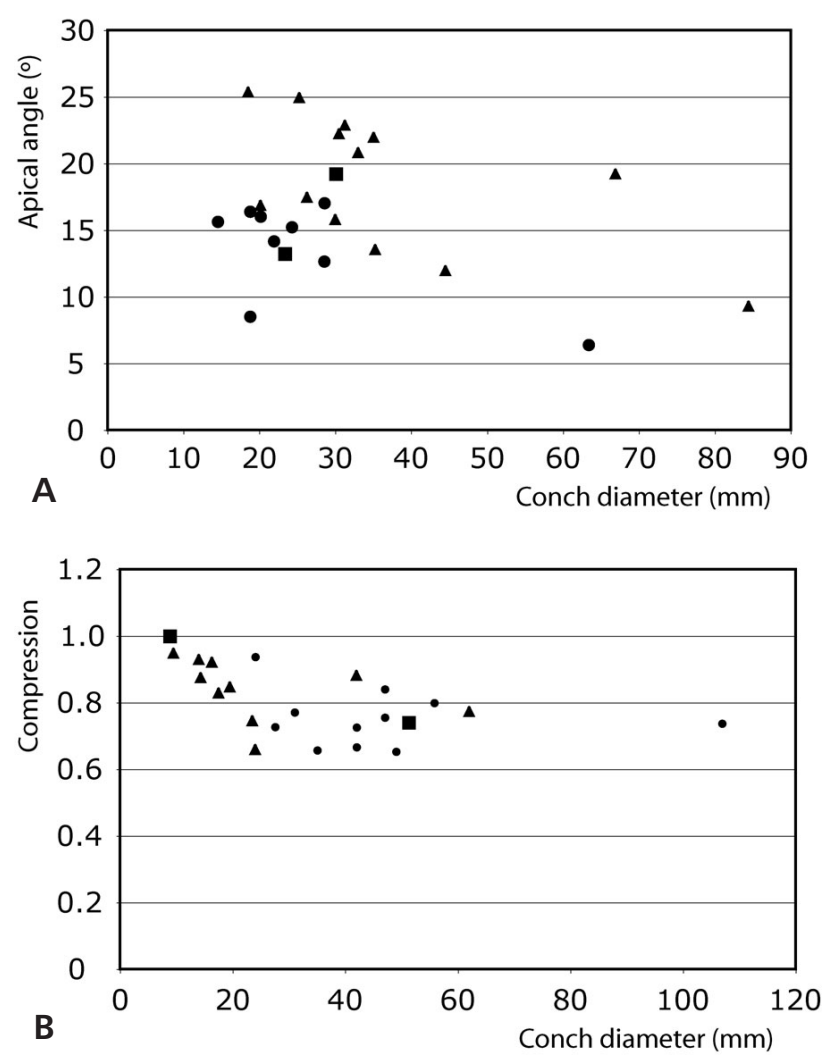

Figure 7. Variation in apical angle (A) and compression of the conch (B) in Protophragmoceras, Phragmoceras and Strandoceras, demonstrating the difficulty of distinguishing between these genera without some indication of the form of the body-chamber. Triangles = Strandoceras $;$ squares = Protophragmoceras ; circles = Phragmoceras . Data from Strand (1934), Sweet (1958), Flower \& Teichert (1957), Evans (1988), Holland \& Stridsberg (2004), Manda (2008).

Remarks. - Flower \& Teichert (1957, p. 57) noted that Strandoceras Flower was erected for Ordovician species previously assigned to Protophragmoceras. They distinguished Strandoceras from Protophragmoceras on the grounds that the latter possessed a smaller siphuncle with the greatest expansion of the siphuncular segment at its anterior end, whilst the septal necks were very short and recumbent. Dzik (1984, pp. 47, 57) treated Strandoceras as a junior synonym of Protophragmoceras but did not provide detailed reasoning for this treatment. Analysis of a small sample of taxa including species of Phragmoceras, Protophragmoceras and Strandoceras (Fig. 7) suggests that it is difficult to distinguish between Protophragmoceras and Strandoceras on grounds of the gross morphology of the conch, and although it appears to be possible to attain a degree of separation between Phragmoceras and both Protophragmoceras and Strandoceras on the basis of the relative expansion of the siphuncular segments, no such distinction appears possible between Strandoceras and Protophragmoceras. Perhaps the only distinction that may be made between these two genera are the well-developed 
bullettes present in the type species of Strandoceras, $P$. tyriense Strand (1934, pl. 13, figs 3, 4) and also in S. strandi Sweet (Sweet 1959, pl. 21, fig. 1). However, bullettes are variably developed in other taxa that have been assigned to Strandoceras - e.g. S. sonax (Salter) (see Evans 1996, pl. 21e), and their distribution amongst Silurian taxa assigned to Protophragmoceras appears to be relatively suppressed (e.g. taxa illustrated by Flower \& Teichert 1957). Bullettes appear to be well developed in some taxa assigned to Phragmoceras [Phragmoceras sp. C (Flower \& Teichert 1957, pl. 43)], and might suggest that Phragmoceras represents a lineage with well-developed bullettes derived from species such as $S$. tyriense. The conch sculpture seen in these three genera appears to show a degree of variation. This may simply reflect difference in the curvature and rate of expansion of the conchs, although the small angle of expansion apparent the strongly curved Endoplectoceras (Flower \& Teichert 1957, pl. 40, figs 1-4) suggests that the increase in the angle between growth lines and sutures reflects the development of a modified aperture during ontogeny. Nevertheless, the angle that the transverse striae make with the sutures on the antisiphonal side of the conch in Strandoceras (Strand 1934, pl. 8, fig. 1a) is relatively small (ca 35 degrees), whilst that seen in Phragmoceras [e.g. P. undulatum Hedström (see Holland \& Stridsberg 2004, fig. 3f)] is high ( $c a 75$ degrees), and lies at intermediate angles in Protophragmoceras (e.g. Flower \& Teichert 1957, pl. 39).

\section{Protophragmoceras? sp.}

Figure 8A-F

Material. - NMW2014.5G.28, from the Pentamerus Beds, unit B15, Gerdu Valley 1 section, Kuh-e Saluk, 35 km south of Bojnurd, Iran.

Description. - This specimen consists of part of a weakly cyrtoconic phragmocone $35 \mathrm{~mm}$ long with a compressed cross-section. At the apical end the dorso-ventral diameter is $19 \mathrm{~mm}$ and the lateral diameter $16.6 \mathrm{~mm}$ (compression $=0.87$ ). At the adoral end, the diameters are $30.0 \mathrm{~mm}$ and $23.6 \mathrm{~mm}$ respectively (compression $=0.78$ ) giving rates of expansion of $23^{\circ}$ in the dorsoventral plane and $15^{\circ}$ in the lateral plane; thus becoming increasingly compressed adorally. The cross-section of the phragmocone is narrowly rounded on the concave side (ventral) of the phragmocone and more broadly rounded on the convex (dorsal) side. The sutures form broad, shallow lobes on the lateral surfaces that are deepest toward the venter, form a faintly angular saddle over the venter, and a more broadly rounded saddle over the dorsum. The depth of the septum is estimated to be about $17 \%$ of the dorsoventral diameter of the phragmocone, and the cameral depth ranges from $18 \%$ to $20 \%$ of the dorsoventral diameter. The siphuncle is marginal in position, lying on the concave side of the phragmocone, with its centre $7 \%$ of the way across the diameter of the phragmocone and the diameter of the septal foramen is $0.6 \%$ of the phragmocone diameter. Since there is only one specimen, and the state of preservation of the siphuncle is uncertain, it has not been sectioned. Nevertheless, at the adapical end of the specimen (Fig. 8F), the septal foramen exhibits a distinct scar suggesting the presence of a strongly recumbent cyrtochoanitic septal neck.

The wall of the internal mould of the phragmocone shows a series of longitudinal ridges and grooves around its circumference (Fig. 8C) that represent the tracks of muscle attachment scars. The poor preservation of parts of the ventral and dorsal surfaces makes it difficult to quantify the number of tracks present with certainty, but there are estimated to be thirty-six in all.

Remarks. - Since this specimen consists only of the phragmocone, and nothing is known of the body-chamber, the shape of the aperture, or the pattern formed by the conch sculpture, this specimen is assigned to Protophragmoceras with some uncertainty; although the relatively small curvature of the conch may suggest Protophragmoceras rather than Phragmoceras. Nevertheless, this specimen provides clear evidence for the presence of a member of either the Protophragmoceratidae or Phragmoceratidae in the Qarebil Limestone Formation assemblage.

Order Barrandeocerida Flower in Flower \& Kummel, 1950 Family Uranoceratidae Hyatt in Zittel, 1900

\section{Genus Glyptodendron Claypole, 1878}

Type species. - Glyptodendron eatonense Claypole, 1878 (p. 308) from the Brassfield Limestone (Llandovery Series) of Eaton and Dayton, Ohio, USA. By monotypy.

Remarks. - Originally identified as a plant by Claypole (1878), the type species was recognised as a cephalopod by Foerste (1893) and tentatively assigned to the Westonoceratidae of the Discosorida by Flower (1946, p. 510) and regarded as being derived from Faberoceras (Flower ibid., p. 518). It was later more firmly assigned to the family by Flower \& Teichert (1957) who considered that the genus was specialised through simplification of its internal structures; regarding the bullettes as vestigial or wanting, and the paretial deposits as missing in those specimens studied. In neither of the sections illustrated by Flower \& Teichert (1957, pl. 25, fig. 5, pl. 26, fig. 3) is there any feature that could be convincingly interpreted as a bullette. Dzik (1984, p. 154) assigned the genus to the Uranoceratidae and went so far as to treat it, together with Cliftonoceras Flower in 


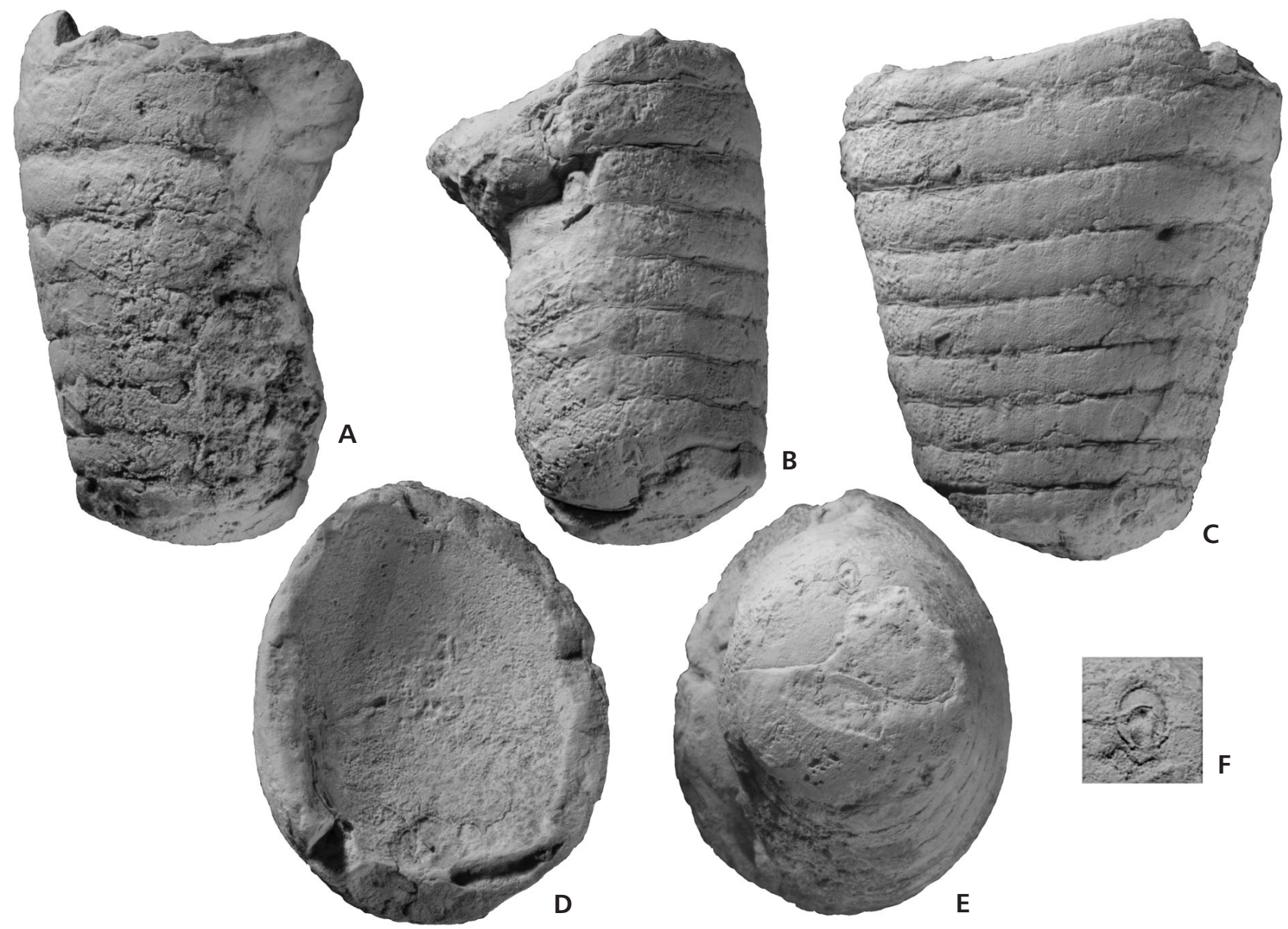

Figure 8. Cephalopods from the Qarebil Limestone Formation. Protophragmoceras? sp. • A-F - NMW2014.5G.28, unit B15, Gerdu Valley 1 section. - A-E; dorsal, ventral, lateral (venter on left), adoral and apical (both venter up) views of phragmocone; $\times 1.25 . \bullet \mathrm{F}-$ detail of septal foramen on apical septal surface; $\times 6.0$.

Flower \& Teichert, 1957, and Cumingsoceras Flower in Flower \& Kummel, 1950 as synonyms of Uranoceras Hyatt, 1884. Whilst such a treatment seems appropriate for Cumingsoceras and was accepted by Turek (2008), this may not be so for Cliftonoceras which has a subventral siphuncle, or Glyptodendron, that possesses a very characteristic shell sculpture combined with a siphuncle that is somewhat more inflated than that seen in Uranoceras. Illustrations of topotype material of Glyptodendron subcompressum (Beecher, 1886) (Flower \& Teichert 1957, pl. 25, figs $1-5$, pl. 26, figs 1-3) indicate that there is some variation in the position of the siphuncle, but show quite clearly a transverse phragmocone cross-section similar to that of Uranoceras or Cliftonoceras that may belong to an extremely evolute, but rapidly expanding planispiral conch. On the basis of the overall form of the known material assigned to Glyptodendron, their similarity to members of the Uranoceratidae suggest that the genus would be more appropriately assigned to that family.

\section{Glyptodendron? sp.}

Figures 9A-C, 10A, B

Material. - NMW2014.5G.27. A single specimen consisting of a portion of phragmocone $120 \mathrm{~mm}$ long. From unit B-11/C of the Gerdu Valley 1 section, $1.5 \mathrm{~km}$ west of the road, Kuh-e Saluk, Kopet-Dagh.

Description. - The specimen consists of a portion of whorl about $120 \mathrm{~mm}$ long which at mid-length has a dorsoventral diameter of $81 \mathrm{~mm}$ and a lateral diameter of $64.5 \mathrm{~mm}$ giving a compression ratio of 0.78 . Within the preserved length of phragmocone the whorl expands at about 14 degrees. The cross-section of the whorl is faintly trapezoidal, with the lateral diameter on the dorsal side being slightly narrower than that on the ventral side (Fig. 10A). The lateral flanks are relatively flat whilst the dorsal side is more narrowly rounded than the ventral side, which shows no sign of an impressed zone.

The sutures are about $17 \mathrm{~mm}$ apart on the lateral surface, 


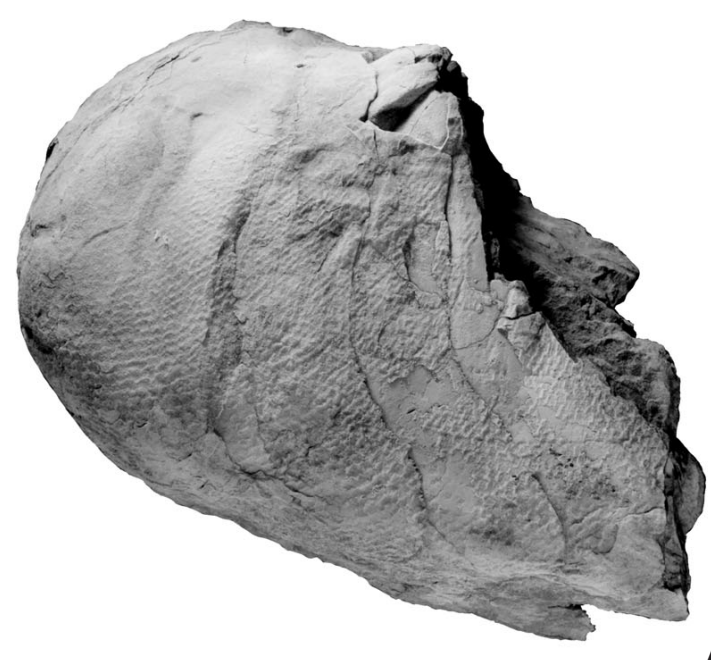

A

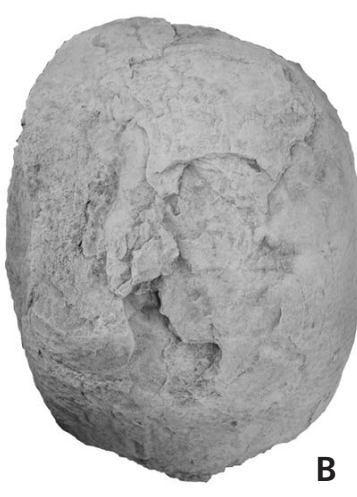

C

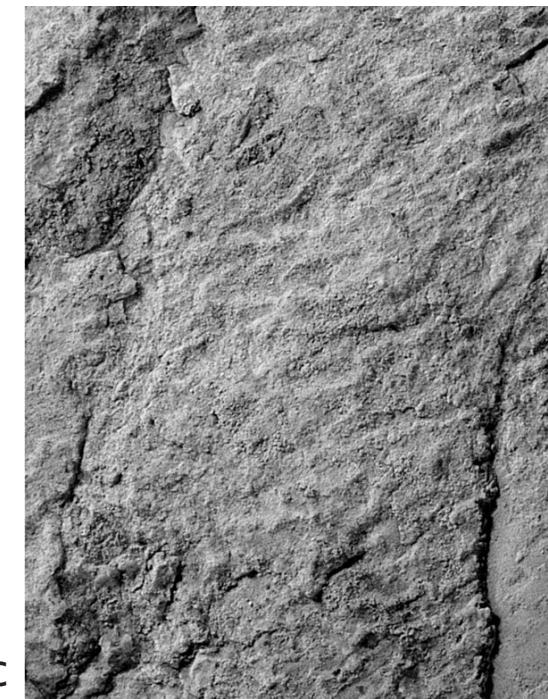

Figure 9. Cephalopods from the Qarebil Limestone Formation. Glyptodendron? sp. • A-C - NMW2014.5G.27, unit B-11/C of the Gerdu Valley 1 section. $\bullet$ A - lateral (venter down) view of portion of whorl of phragmocone showing sutures and conch sculpture; $\times 0.6$. $\bullet \mathrm{B}-$ apical view of phragmocone (venter down); $\times 0.6$. $\bullet \mathrm{C}-$ detail of conch sculpture; $\times 3.0$.

indicating a cameral depth of $21 \%$ that of the dorsoventral diameter of the whorl. They form broad lobes on the lateral surfaces that extend into pronounced saddles on the ventrolateral surfaces, and are then deflected apically to form a lobe over the venter, whilst saddles on the dorsoventral surfaces and a broad dorsal lobe are substantially less pronounced (Fig. 9A, 10B). The depth of the most apicad septum is about $26 \mathrm{~mm}$, or approximately $34 \%$ of the dorsoventral diameter of the phragmocone. It is just possible to discern the septal foramen, the edge of which lies $36 \mathrm{~mm}$ from the venter and a dorsoventral diameter of $7.7 \mathrm{~mm}$ and a lateral diameter of $5.5 \mathrm{~mm}$, so that the siphuncle is central in position.

The conch sculpture is preserved on the ventral and lateral surfaces of the phragmocone and takes the form of a rugose, scale-like, but regular and faintly reticulate surface with a granularity of $1 \mathrm{~mm}$ arising from the interference of growth lines with lineations oriented parallel to the axis of the whorl. The growth lines are directed apically toward the venter in a broad arc, forming a sinus $25 \mathrm{~mm}$ deep over the venter as measured from the ventral edge of the lateral flank of the phragmocone. The lineations are about 1.5-2.0 $\mathrm{mm}$ apart but vary in prominence, with the most prominent about $12 \mathrm{~mm}$ apart on the lateral surfaces, but about $2.0 \mathrm{~mm}$ distant on the venter.

Remarks. - The lack of an impressed zone on the dorsal surface of the phragmocone indicates that for this portion at least, the whorls were free of each other and the conch was probably gyroconic. Comparison of the rate of expansion, conch cross-section and the cameral depth of the preserved portion with other taxa assigned to the Uranoceratidae (in- cluding Glyptodendron) indicates that this specimen falls within their ranges (Fig. 11), although the significance of this cannot be tested without additional material and the capacity to standardise the measurements; particularly in relation to the rate of expansion. Comparison with illustrations of topotype material of Glyptodendron subcompressum (Beecher) (Flower \& Teichert 1957, pl. 25, figs $1-5$, pl. 26, figs 1-3) suggests a marked similarity with the material described above, particularly with regard to the overall shape (ibid., pl. 25, fig. 1) and cross-section (ibid., pl. 25, fig. 2), but exhibits a strong ventrolateral lobe, unlike G. subcompressum. "Nautilus" oceanus (Hall, 1847), described and refigured by Foerste (1925, p. 35, pl. 3, fig. 3, pl. 9, fig. 1, pl. 17, fig. 1), is similar to the material under discussion in possessing a strong ventrolateral lobe, but nothing is known of the shell sculpture or of the siphuncle.

The shell sculpture and overall form of this specimen invites assignment to Glyptodendron, but given that this would represent the only specimen known outside North America, combined with paucity of North American material there is little justification for proposing a new species founded on this individual.

Subclass Orthoceratoidea McCoy, 1844

Order Orthocerida Kuhn, 1940

Family Geisonoceratidae Zhuravleva, 1959

\section{Genus Protokionoceras Grabau \& Shimer, 1910}

Type species. - Orthoceras medullare Hall, 1868, p. 353, 

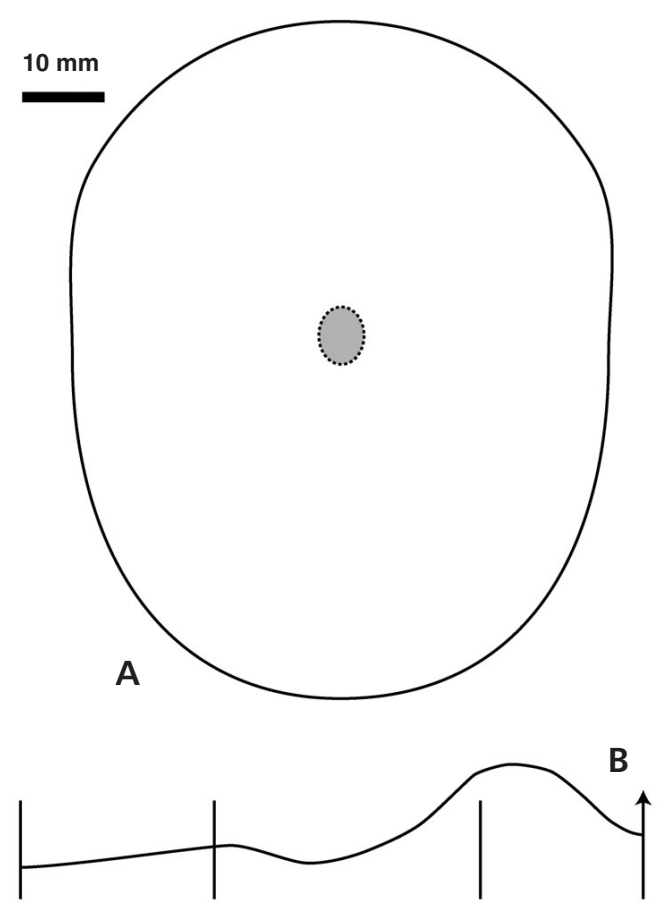

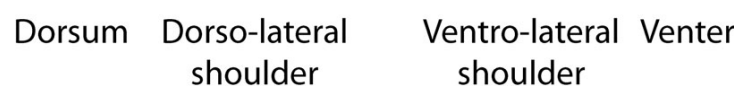

Figure 10. Glyptodendron? sp. - A - idealised profile of conch cross-section (apical view) based on NMW2014.5G.27. • B - shape of suture; not to scale.

pl. 20, figs 1, 2. From the Racine Dolomite of Waukesha, Wisconsin, USA. By original designation.

Remarks. - Protokionoceras is characterised by a conch that lacks annulations and possesses a sculpture consisting of prominent longitudinal lirae or striae and more subordinate transverse striae. The internal structure of the type genus is apparently unknown, but in other species assigned to the genus the siphuncle is considered to be tubular ( $P$. crooki Foerste, 1928, p. 308), whilst the endosiphuncular and cameral deposits were regarded as similar to those of $\mathrm{Gei}$ sonoceras (Sweet 1964a) and Niko et al. (1989, p. 63) reported the presence of suborthochoanitic septal necks, combined with slightly expanded connecting rings, particularly on the dorsal side, as well as mural cameral deposits. Given that the internal form of the types species, and several other species (e.g. Late Ordovician P. strandi Troedsson, 1932) is unknown, it is possible that the genus may be something of a taxonomic dustbin. This will not be easily resolved without better knowledge of the type species.

\section{Protokionoceras sp.}

Figure 12A-B, F, G, J

Material. - NMW2014.5G.6, unit B9b, Gerdu Valley 1
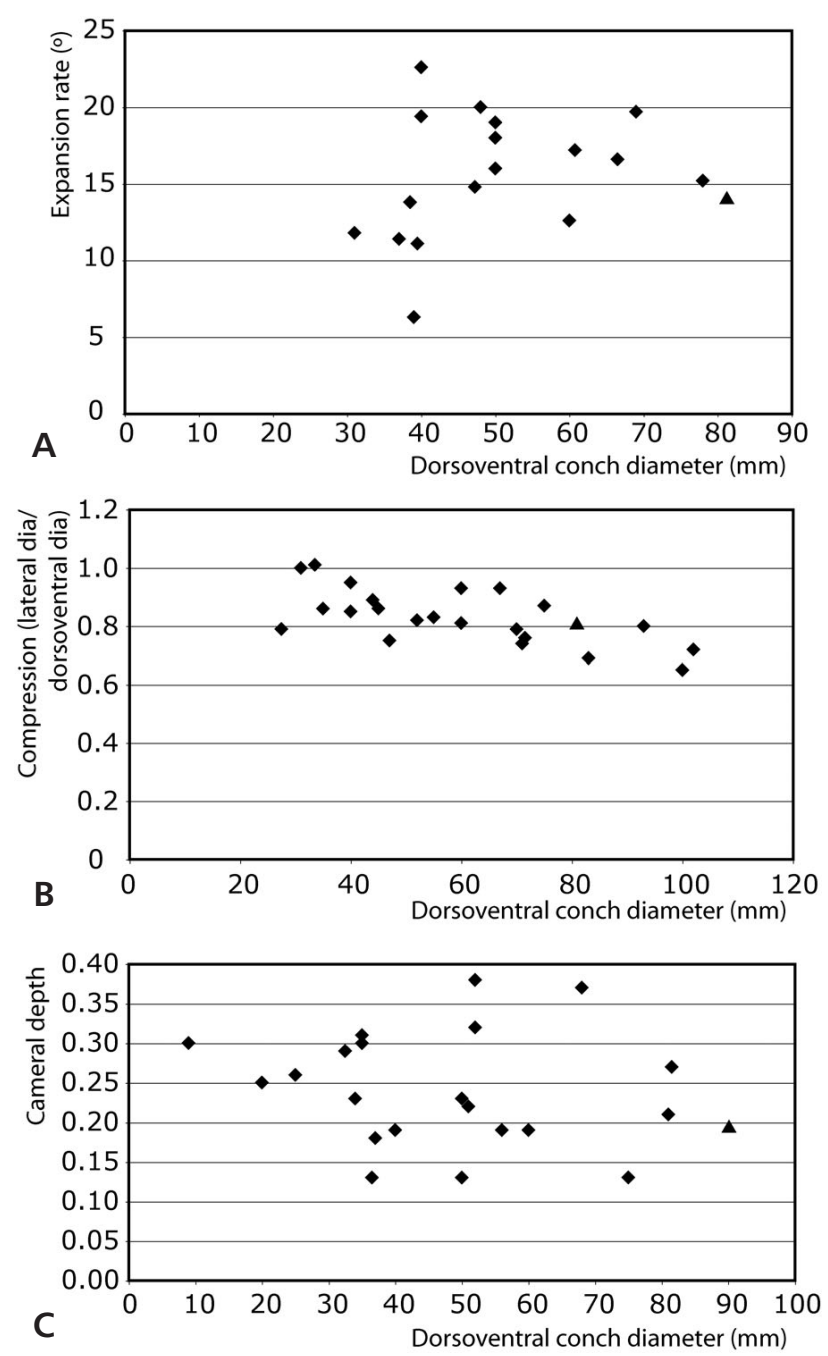

Figure 11. Variation in conch expansion rate (A), compression (B), and cameral depth (C) with conch diameter for several taxa assigned to the Uranoceratidae. Glyptodendron? sp. (NMW2014.5G.27) indicated by triangular data points. Data from Barrande (1886, pl. 196), Foerste (1925, pls $1-3,5-7,10,11,13,15,17)$, Mutvei (1957, pl. 17).

section, Kuh-e Saluk, Kopet-Dagh; NMW2014.5G.13, unit 11, Gerdu Valley 1 section, Kuh-e-Saluk Mountains, Kopet-Dagh.

Description. - NMW2014.5G.13 is a somewhat worn phragmocone $50 \mathrm{~mm}$ long that increases in diameter from $25.0 \mathrm{~mm}$ to $27.5 \mathrm{~mm}$ in $24 \mathrm{~mm}$, giving an apical angle of $6^{\circ}$. The sutures are straight but slightly inclined to the plane normal to the conch axis and about $9 \mathrm{~mm}$ apart, giving a cameral depth $37 \%$ that of the phragmocone diameter. The depth of the septa are $24 \%$ that of the phragmocone diameter. The sutures are straight directly transverse. The shell sculpture consists of raised longitudinal lirae with a density of 8 per $\mathrm{mm}$ and are alternatively more and less pronounced. Transverse striae are also present and where seen have 
a density of 10 per mm, but are very much less prominent than the longitudinal lirae and are not discernable over large areas of the preserved parts of the conch wall. The septal foramen is $2.9 \mathrm{~mm}$ in diameter, or $10 \%$ of the phragmocone diameter. The siphuncle is almost central in position, with the centre $47 \%$ of the way across the diameter of the phragmocone. The septal necks are orthochoanitic to suborthochoanitic and 0.8 to $1.0 \mathrm{~mm}$ in length. The connecting rings are extremely fragmentary and are only seen at one septal foramen (Fig. 12B) where the remaining fragments suggest that the connecting ring was slightly inflated. Endosiphuncular deposits in the form of small annuli at the septal necks suggest that the connecting rings were at least slightly expanded.

The second specimen, NMW2014.5G.6 is a partially weathered and worn phragmocone $38 \mathrm{~mm}$ long and expanding in diameter from 15.5 to $18.8 \mathrm{~mm}$ in a length of $24.5 \mathrm{~mm}$, indicating an apical angle of almost $8^{\circ}$. Where the conch is not too worn, the sutures appear to be straight, but faintly inclined to the normal of the conch axis. The depth of the septa is $23 \%$ that of the phragmocone diameter whilst the cameral depth is $31 \%$. The diameter of the septal foraminae ranges from 8.5 to $10 \%$ that of the phragmocone. The septal foraminae lie about $48 \%$ of the way across the diameter of the phragmocone. The connecting rings are entirely missing, but the septal necks are orthochoanitic and $0.35 \mathrm{~mm}$ long. Although extremely worn, a small area toward the apical end of the specimen exhibit faint raised longitudinal lirae with a density of 10 per $\mathrm{mm}$. The preservation is too poor to discern the presence of any transverse striae.

Remarks. - The shell sculpture, particularly that seen in NMW2014.5G.13 is generally similar to that described from other species of Protokionoceras, whilst the presence of annuli at the septal necks may support an assignment to the Geisonoceratidae. The material described here is not sufficiently well preserved to compare with other taxa assigned to the genus in any detail, although it is noted that by comparison with the type species, only primary and secondary longitudinal striae are evident in the surface of the conch.

\section{Geisonoceratidae gen. et sp. indet.}

Figure 12D, H, I, K, L

Material. - NMW2014.5G.29, unit B9A, Gerdu Valley 1 section. NMW2014.5G.3, 24, unit B9B, Gerdu Valley 1 section. NMW2014.5G.25, unit 7, Gerdu Valley 2 section. NMW2014.5G.4, unit B9C, Gerdu Valley 1 section. NMW2014.5G.1, 2, 11, 19, unit B11), Gerdu Valley 1 section. NMW2014.5G.18, unit U-5, Gerdu Valley 2 section. NMHUK Pl CN140, Rabat-e Qarebil.
Description. - These specimens consist of portions of phragmocone ranging from 15 to $67 \mathrm{~mm}$ in diameter. The apical angle ranges from $2^{\circ}$ to $12^{\circ}$ and may increase with the diameter of the phragmocone, although the difficulty of obtaining this measurement with the material to hand makes this uncertain. Similarly, the wear at the sutures affects an assessment of septal depth, which appears to lie between $24 \%$ and $32 \%$ of the phragmocone diameter $($ mean $=26 \%)$. Cameral depth decreases from $42 \%$ of the phragmocone diameter to $15 \%$ with the increasing diameter of the phragmocone, but may then increase slightly with further growth of the conch (Fig. 13A). The septal foraminae lie between 11 and $14 \%($ mean $=12 \%)$ of the phragmocone diameter whilst their position appears to migrate (Fig. 13B) from subcentral position $34 \%$ of the way across the phragmocone diameter to more central (44\%) with the growth of the conch. The siphuncle is poorly preserved and the connecting ring appears to be entirely missing in all the specimens that were sectioned. The septal necks, as seen in NMW2014.5G.3 (Fig. 12K) are $1 \mathrm{~mm}$ long (diameter of phragmocone $36 \mathrm{~mm}$ ) and lie between loxochoanitic and orthochoanitic in shape. There is no evidence of the presence of endosiphuncular or cameral deposits in any of the specimens that were sectioned.

No conch sculpture is evident in any of the specimens, and it may be only in NMHUK Pl CN140 that the outer form of the conch can be seen. In this specimen (Fig. 12I), the phragmocone appears to be weakly annulate, with the low culminations lying about halfway between adjacent sutures and the troughs lying in the sutures.

Remarks. - Although representing a substantial component of this assemblage and likely to consist of a single taxon, the preservation of this material makes any assignment of this material, including its possible referral to the Geisonoceratidae very uncertain. In terms of their gross form these conchs bear a degree of resemblance to Temperoceras Barskov, 1960, which is known from horizons as old as the late Llandovery of Kazahkstan (Barskov 1972).

Family Kionoceratidae Hyatt in Zittel, 1900

\section{Genus Kionoceras Hyatt, 1884}

Type species. - Orthoceras doricum Barrande, 1886, pl. 269. From the lower part of the L. scanicus-S. chimaera Zone of the Kopanina Formation (Gorstian Stage, Ludlow Series) of the Prague Basin, Czech Republic.

Remarks. - Hyatt (1884, p. 275) proposed Kionoceras for longicones with longitudinal lirae that are more prominent than the transverse lirae or striae. Taxa assigned to the genus range from the Middle Ordovician (Flower 1952) to the 

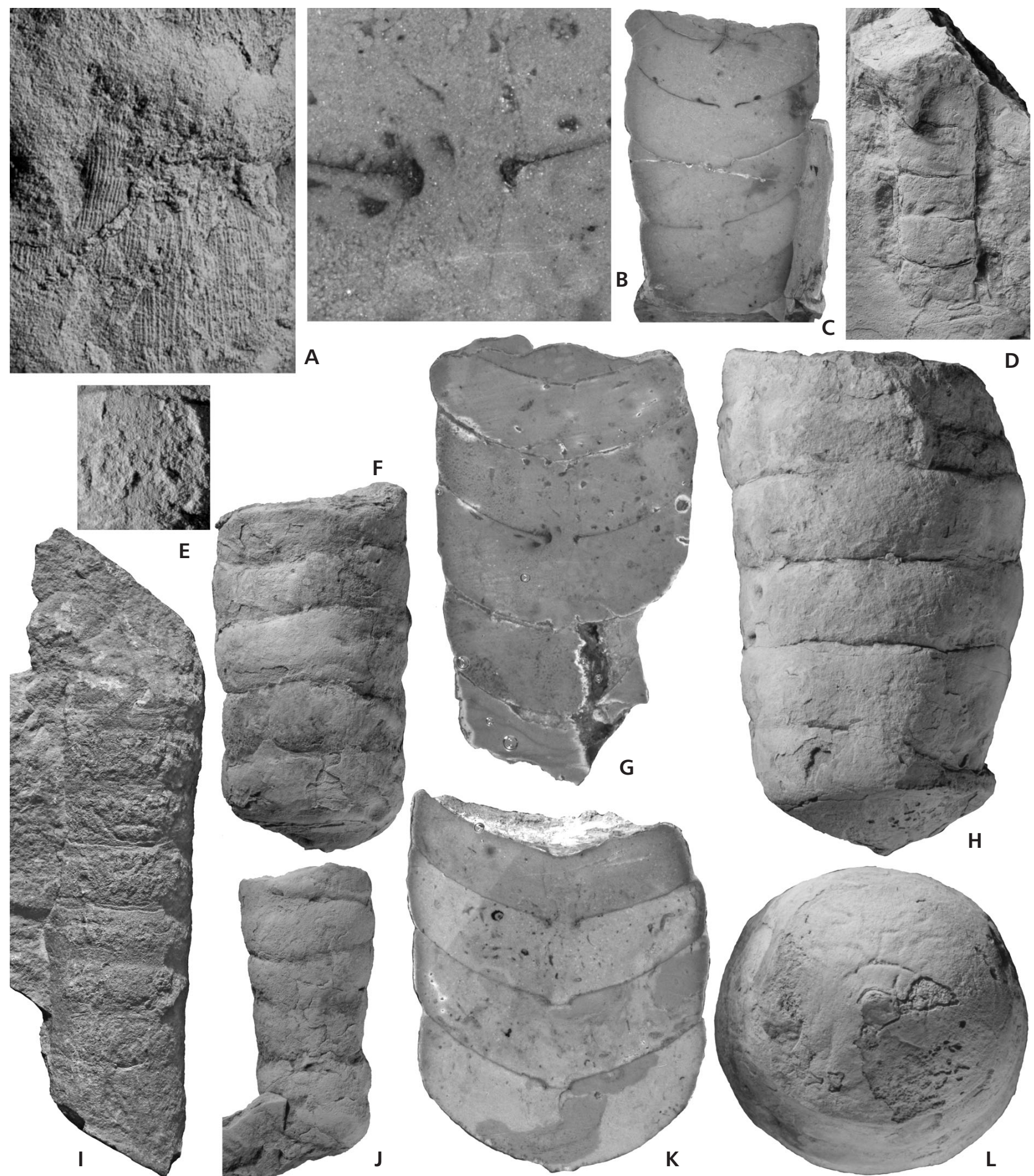

A
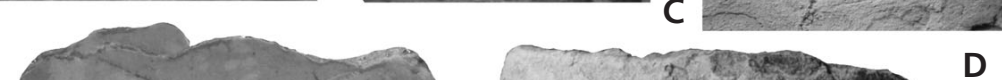

E
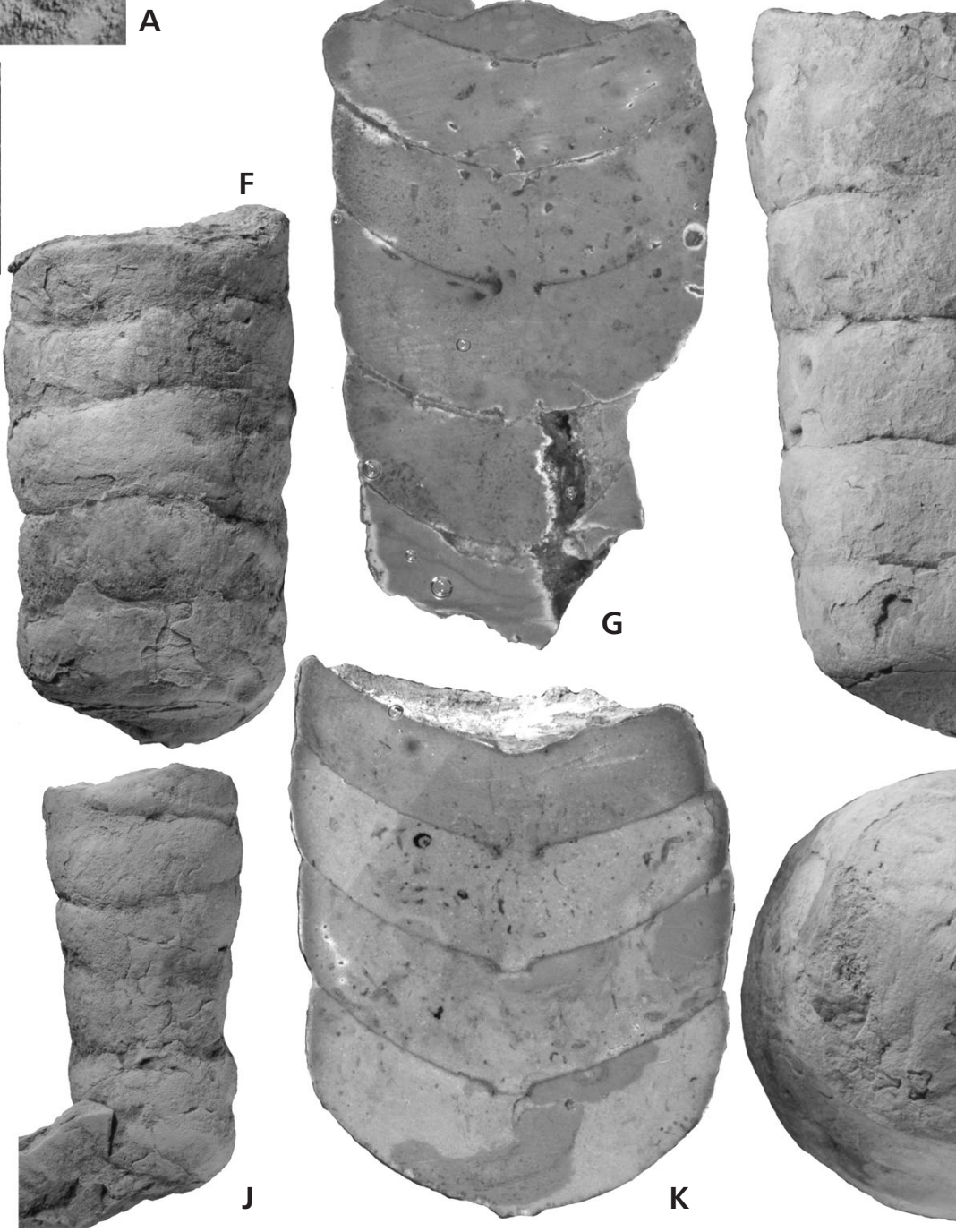

Figure 12. Cephalopods from the Qarebil Limestone Formation. • A-C, E-H, J - Protokionoceras sp. • A, B, F, G - NMW2014.5G.13, unit 11, Gerdu Valley 1 section. $\bullet$ A - detail of conch sculpture showing raised longitudinal lirae, crossed by transverse striae; $\times 10.0 . \bullet B-$ detail of septal foramen showing fragments of connecting rings and annulosiphonate deposits developed at septal necks; $\times 6.0$. $\bullet \mathrm{F}-$ phragmocone; $\times 1.25$. $\bullet \mathrm{G}-$ cut and polished section through phragmocone. $\bullet$ C, E, J - NMW2014.5G.6, unit B9b Gerdu Valley 1 section. $\bullet$ C - cut and polished section through phragmocone; $\times 1.75$. - E - detail of poorly preserved shell sculpture showing longitudinal lirae; $\times 10.0$. $\bullet \mathrm{J}-$ external view of phragmocone; $\times 1.25 . \cdot \mathrm{D}, \mathrm{H}, \mathrm{I}, \mathrm{K}, \mathrm{L}-$ Geisonoceratidae gen. et sp. indet. $\bullet$ D - NMW2014.5G.25, unit 7, Gerdu Valley 2 section, worn external mould of small phragmocone; $\times 1.25$. $\bullet \mathrm{H}, \mathrm{K}, \mathrm{L}-$ NMW2014.5G.3, unit B9B, Gerdu Valley 1 section. $\bullet \mathrm{H}$ - lateral(?) view of phragmocone; $\times 1.25 . \bullet \mathrm{K}-$ sagittal section showing septa and septal necks; $\times 1.25$. $\bullet \mathrm{L}-$ apical view of septal surface; $\times 1.25$. $\bullet \mathrm{I}-\mathrm{NMHUK}$ PI CN140, Rabat-e Qarebil; lateral(?) view; $\times 1.25$. 

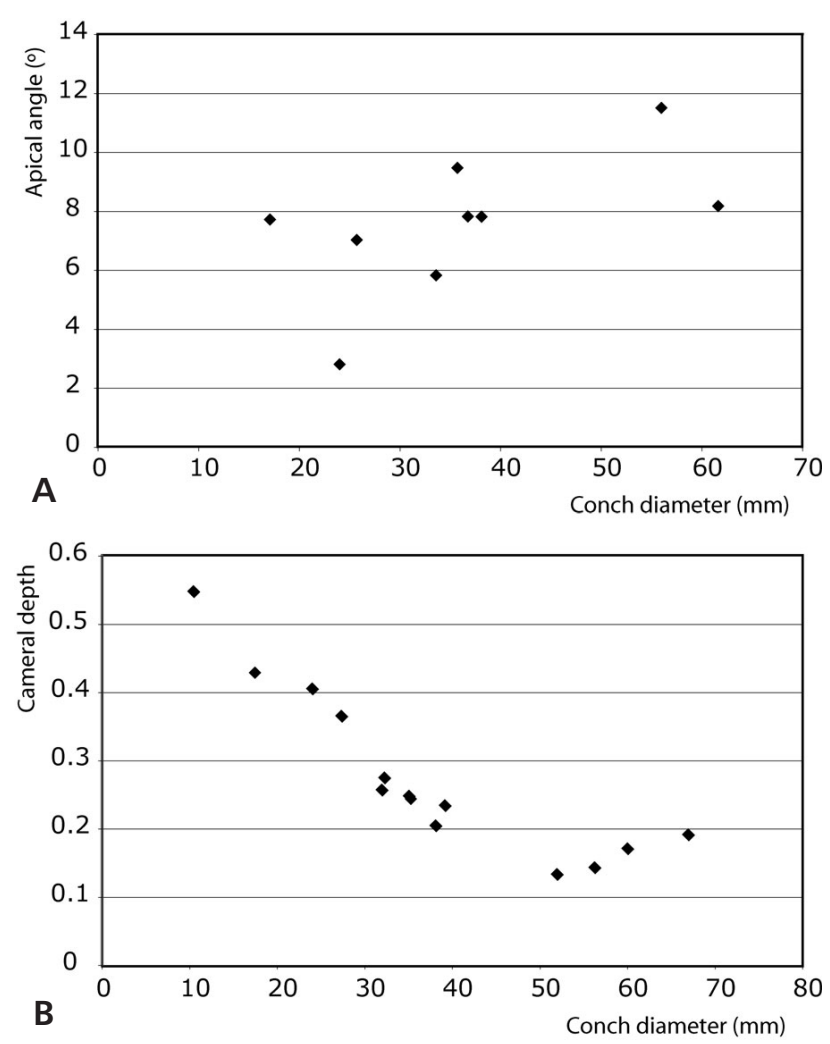

Figure 13. Geisonoceratidae gen. et sp. indet. • A - variation of apical angle with conch diameter. $\bullet B$ - variation of cameral depth with conch diameter, showing an apparently consistent trend of a relative decrease in cameral depth with growth of the conch.

Carboniferous (Niko et al. 2007). In the type species (Barrande 1886 , pl. 29, fig. 26), the siphuncle is relatively narrow, slightly subcentral, with only weakly expanded siphuncular segments. The range of variation in conch sculpture (including the development of weak annulations in some taxa), the morphology of the siphuncle and the presence of endosiphuncular and cameral deposits in some species assigned to Kionoceras indicate that both the genus and the family are likely to include homeomorphic taxa (Flower 1952, Sweet 1959) and have been used as a taxonomic dustbin. At present, both the genus and family may contain a range of taxa belonging to the
Kionoceratidae, Geisonoceratidae, or the Proteoceratidae. It is beyond the scope of this paper to resolve such issues, and the classification, broadly that of Sweet (1964a), although requiring substantial revision, is retained here for convenience.

\section{Kionoceras sp. \\ Figures 14A-C, E-K, M, N, 15A, B}

Material. - Seven specimens: NMW2014.5G.5, unit 5, Gerdu Valley section 2, south of Bojnurd; NMW2014.5G.8, unit U-11, Gerdu Valley section 1, Kuh-e Saluk Mountains, Kopet-Dagh); NMW2014.5G.23, unit B9B, Gerdu Valley section 1; NMW2014.5G.10, 21, unit 7, Gerdu Valley section 2; NMW2014.5G.30, 31, unit B15, Gerdu Valley section 1.

Description. - These specimens consist of internal moulds of phragmocones ranging from $14-23 \mathrm{~mm}$ in diameter. The conch sculpture is preserved only in NMW2014.5G.5 (14 mm in diameter; Fig. 13A, I) where a few patches on the surface of the phragmocone exhibit longitudinal lirae $0.42 \mathrm{~mm}$ apart and $0.07 \mathrm{~mm}$ in width. No transverse striae or lirae are visible. The rate of expansion of the conch ranges from $11^{\circ}$ to $1^{\circ}$ and generally decreases with the increasing diameter of the phragmocone. The sutures are straight, but as indicated by NMW2014.5G31, are clearly inclined so that they slope adapically towards the supposed dorsum. The depth of the septa ranges between $20 \%$ and $26 \%$ that of the phragmocone diameter (mean 24\%). Cameral depth varies from $19.5 \%$ to $25 \%$ of the phragmocone diameter and generally decreases with the increasing diameter of the phragmocone although this is very poorly correlated $\left(\mathrm{R}^{2}=0.14\right)$. The location of the centre of the septal foramen lies between $41 \%$ and $47 \%$ of the way across the diameter of the phragmocone. In most specimens, the siphuncle is damaged, and the connecting rings largely missing. The diameter of the septal foramen ranges from $6.6 \%$ to $10.6 \%$ of the phragmocone diameter (mean $=8.8 \%, \mathrm{~N}=25$ ), and where the connecting rings remain intact (NMW2014.5G.10, 31; Figs 14A-C, E-K, M, N, 15A, B),

Figure 14. Cephalopods from the Qarebil Limestone Formation. • A-C, E-K, M, N-Kionoceras sp. • A, B, I- NMW2014.5G.5, unit 5, Gerdu Valley section 2 . $\bullet$ A - external view of phragmocone; $\times 1.5$. $\bullet$ B - cut and polished section showing septa and septal foraminae; $\times 2.6$. $\bullet$ I - detail of conch sculpture; $\times$ 4.0. $\bullet$ C, J, K, N - NMW2014.5G.31, unit B15, Gerdu Valley section 1. $\bullet$ C - polished section showing details of siphuncular segments (see also Fig. $15 \mathrm{~B}) ; \times 7.2 . \bullet \mathrm{J}-$ external view of phragmocone; $\times 1.0 . \bullet \mathrm{K}-$ cut and polished section through phragmocone; $\times 2.0 . \bullet \mathrm{N}-$ adoral septal surface; $\times 1.25$. • E, H, M - NMW2014.5G.10, unit F-7, Gerdu Valley 2 section. $\bullet$ E - cut and polished sections showing details of the septal foramen and connecting ring (see also Fig. $15 \mathrm{~A}$ ) $\times \times$ 7.0. $\bullet \mathrm{H}-$ cut and polished section of phragmocone; $\times 2.5 . \bullet \mathrm{M}-$ external view of phragmocone; $\times 1.25$. $\bullet$ F, G - NMW2014.5G.30, unit B15, Gerdu Valley 1 section; assumed ventral (F) and lateral (G) views of phragmocone; $\times 1.25$. $\bullet$ D, L - Palaeodawsonocerina? sp. NMW2014.5G.16, unit 11, Gerdu 1 section. • D - body-chamber; $\times 1.5$. $・$ L - detail of conch sculpture; $\times 8.0$. $・$ O-Q - Sactoceras? sp. O, P-NMW2014.5G.17, unit B9a, Gerdu Valley section $1 . \bullet \mathrm{O}-$ lateral view of portion of phragmocone; $\times 1.5$. $\bullet$ P - apical view of septal surface; $\times 1.5$. - Q - NMW2014.5G.22, unit U7, Gerdu Valley section 2, lateral view of portion of phragmocone; $\times 2.0$. 
David H. Evans et al. • An early Silurian (Aeronian) cephalopod fauna from north-eastern Iran

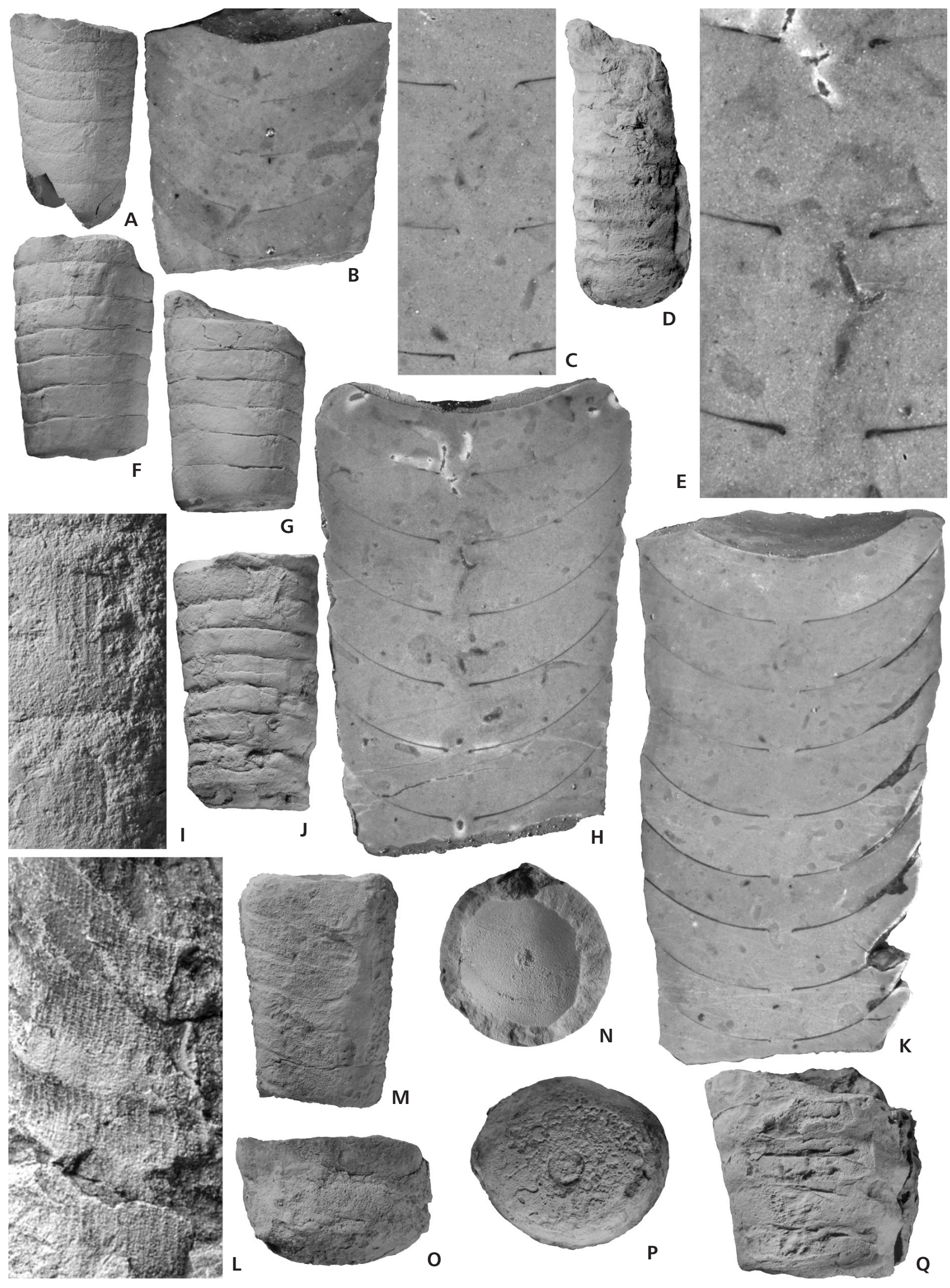



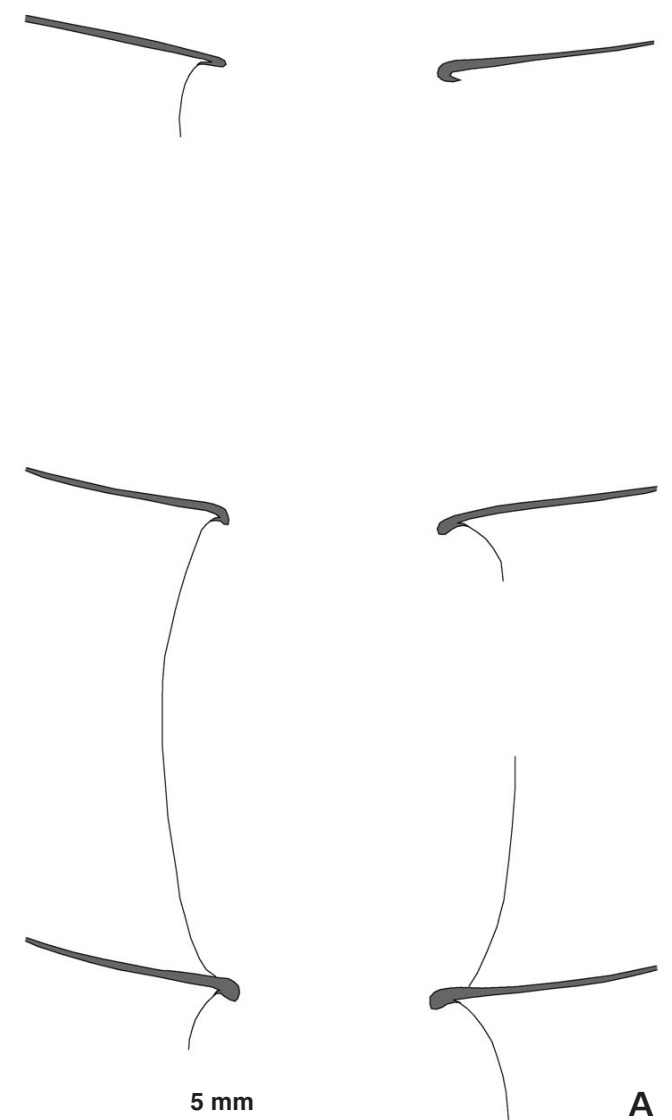

A

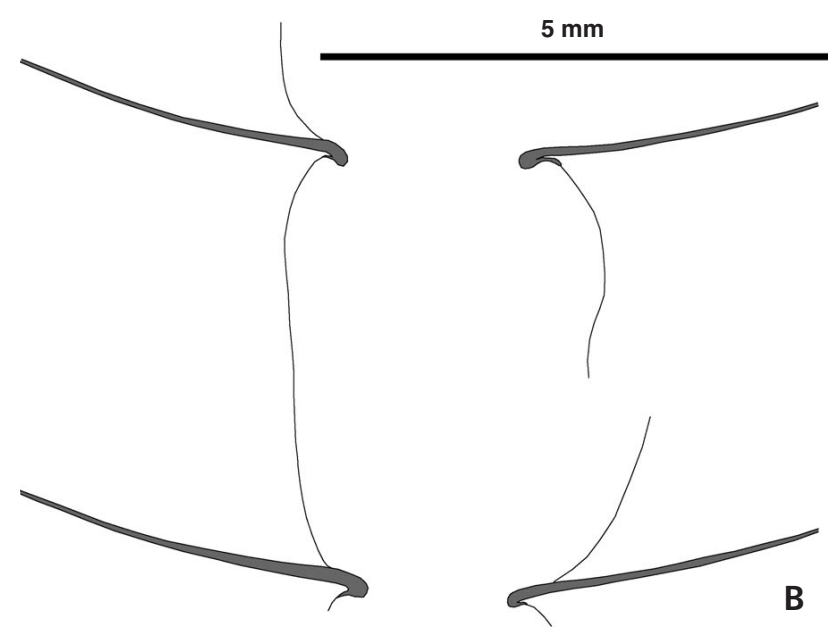

Figure 15. Interpretative sketches of details of siphuncle morphology in Kionoceras sp. • A - NMW2014.5G.10, unit F-7, Gerdu Valley 2 section; interpreted as showing cyrtochoanitic septal necks (see also Fig. 14E, H). • B - NMW2014.5G.31, unit B15, Gerdu Valley 1 section; interpreted as showing cyrtochoanitic septal necks (see also Fig. 14C, K). Both specimens show slight asymmetry with regard to the width of the septal necks indicating that the sections probably lie close to the dorso-ventral plane. their maximum diameter ranges from $15.2 \%$ to $19.9 \%$ of the phragmocone diameter $($ mean $=17.5 \%, \mathrm{~N}=7$ ) whilst the overall degree of inflation ranges from 150-200\% of the diameter of the septal foraminae. The ratio of the width of the septal foramen to the height of the siphuncular segment (Fig. 16) varies from 0.29 to 0.50 (mean $=0.42$, median $=0.43, \mathrm{~N}=20$ ). Where the connecting rings are entirely missing, the septal necks appear to range from achoanitic to loxochoanitic, to faintly orthochoanitic. This is misleading, as where the connecting rings are intact or partially intact, they are at a very low angle to the plane in which the septal foramen lies, suggesting that the septal necks are in fact cyrtochoanitic. The septal neck in NMW2014.5G.10 (Figs 14E, 15A) is $0.28 \mathrm{~mm}$ long and the recumbent brim $0.28 \mathrm{~mm}$ wide on one side of the septal foramen. The connecting ring expands rapidly in the adoral part of the segment, but contracts more slowly in the adapical half and is attached to the adapical septal neck by an episeptal adnation area $0.40 \mathrm{~mm}$ wide. On the other side of the septal foramen, the brim is $0.37 \mathrm{~mm}$ in width, and the episeptal adnation area $0.5 \mathrm{~mm}$, whilst the connecting ring inflates further into the camerae, indicating a degree of dorsoventral asymmetry in the profile of the segments. As there is no indication on the external surfaces of the moulds to suggest the correct dorsal-ventral orientation of these specimens, it is not possible to determine the absolute degree of this asymmetry.

No endosiphuncular or cameral deposits are evident in any of the specimens.

Remarks. - Despite the lack of the conch sculpture characteristic of Kionoceras in all but one of the specimens, combined with the lack of preserved connecting rings in that specimen (NMW2014.5G.5), the ratio of the diameter of the septal foramen to the height of the siphuncular segment (Fig. 15) suggests that they belong to a single taxon and are distinct from the other orthocerids so far collected from this part of the Qarebil Limestone Formation.

Whilst Kionoceras doricum is represented by a phragmocone possessing a relatively narrow siphuncle with very slightly inflated, almost tubular segments (Barrande 1868, pl. 269, fig. 26), amongst Ordovician and Silurian taxa that have been assigned to the genus are forms where the siphuncle may be moderately (Orthoceras bacchus Barrande, 1868, pl. 270, fig. 7, late Wenlock of Bohemia), to considerably more inflated [e.g. Kionoceras arctuatum (Angelin in Angelin \& Lindström, 1880) - see Troedsson 1932, pl. 3, fig. 1], where the dorsoventral sagittal section of the siphuncle resembles that of Proteoceras Flower, 1950. Endosiphuncular deposits may also be evident (e.g. Kionoceras bacchus - see Barrande 1868, pl. 271, fig. 21). One specimen (from Poland) possessing well-developed cameral deposits was assigned to $K$. cf. doricum by Dzik (1984, fig. 48c). This specimen also exhibits a weakly 
Figure 16. Plot of the ratio of the diameter of the septa foramen to the distance between the septal foraminae versus the relative diameter of the septal foraminae. This appears to provide a criterion allowing distinction between specimens that cannot be resolved from the outward form of the phragmocone in many specimens from the Qarebil Limestone Formation.
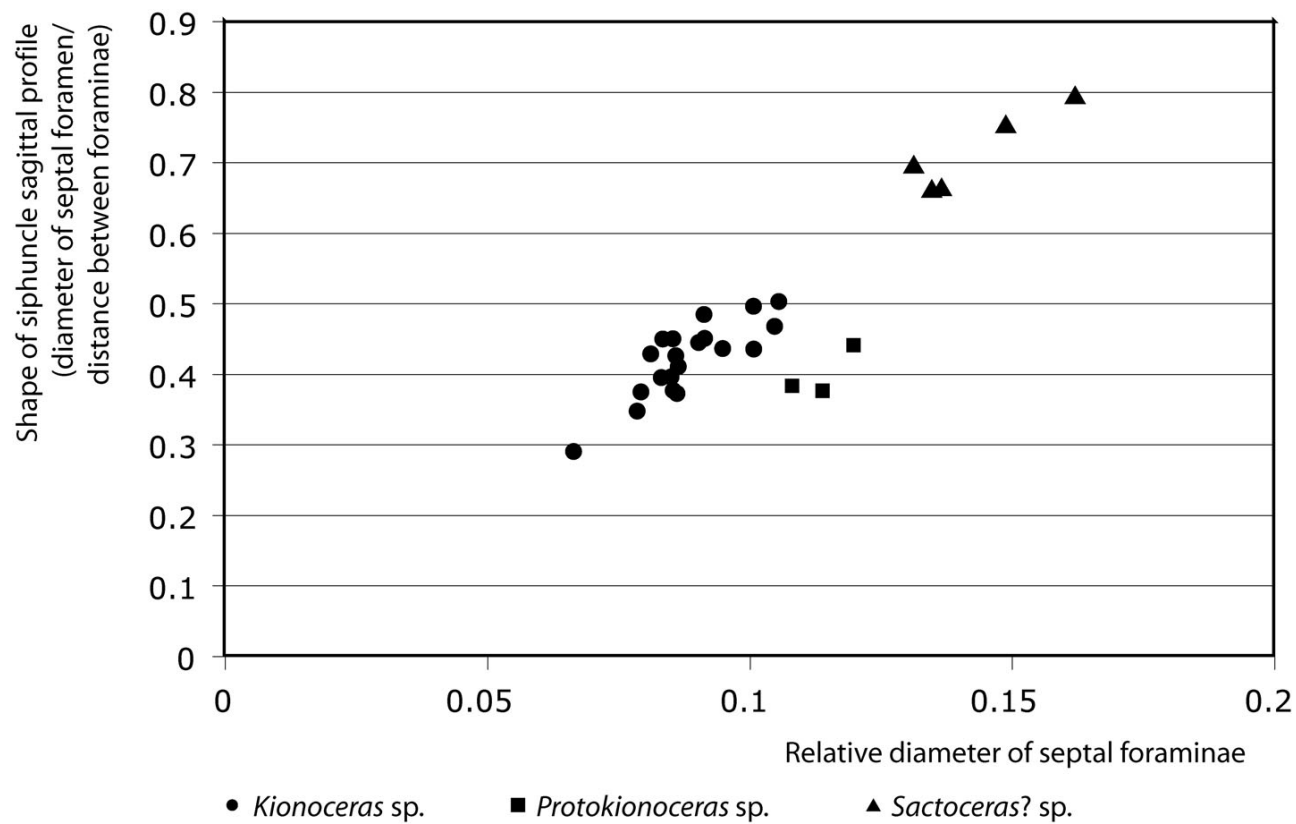

annulate conch. Dzik suggested that during the Ludlow in the Prague Basin, Kionoceras was represented by two species: K. doricum and K. bronni (Barrande, 1868). Whilst distinguishing between these taxa on the grounds of the conch sculpture, he made no comment regarding the presence of a broader, more inflated siphuncle that appears to show annulosiphonate deposits at the septal foraminae (Barrande 1868, pl. 258, fig. 9) as well as episeptal cameral deposits (Barrande 1868, pl. 258, fig. 8) in the latter species.

Kionoceras electum (Barrande, 1868) from the earlier Ludlow of Bohemia was regarded as an ancestor of K. doricum (Manda \& Kříž 2007). In one of the specimens of $K$. electum that Barrande figured (Barrande 1868, pl. 260, fig. 24), he noted the presence of cameral deposits. There also appear to be endosiphuncular deposits on one side of the siphuncle. In $K$. electum, the siphuncle may be slightly broader and the siphuncular segments more expanded. Thus, if the ancestor-descendant relationship between these taxa is real, it would imply that the genus may be defined relatively broadly and might include forms possessing or lacking endosiphuncular and cameral deposits, as well as exhibiting tubular or expanded siphuncular segments. It will not be possible to resolve these issues until the relationship between $K$. doricum and $K$. electum is better understood, and provides a foundation for either restricting Kionoceras to the type species; to a limited group of closely related lineages, or to a range of more morphologically diverse taxa.

As far as the material described above is concerned, the relatively inflated siphuncular segments would indicate that they are more similar to forms such as K. electum or $K$. bacchus rather than $K$. doricum.
Family Dawsonoceratidae Flower, 1962

\section{Genus Palaeodawsonocerina Kröger \& Isakar, 2006}

Type species. - Spyroceras senkenbergi Teichert, 1930, p. 280, pl. 5, figs 3, 4. From the Late Ordovician of Lyckholm, Estonia. By original designation.

Remarks. - Kröger \& Isaker (2006) proposed Palaeodawsonocerina for conchs with narrowly spaced annulations, dense transverse striae, and fine, numerous longitudinal striae, combined with a central to slightly subcentral tubular siphuncle possessing orthochoanitic septal necks. Although only describing the type species, they noted (ibid., p. 154) that a number of Late Ordovician and Silurian taxa referred to Anaspyroceras Shimizu \& Obata and Spyroceras Hyatt might be better placed in Palaeodawsonocerina on the grounds of the similarity of the conch sculpture, although the morphology of the siphuncle was poorly known in these forms, and was probably the reason they refrained from naming any such taxa.

\section{Palaeodawsonocerina? sp.}

Figure 14D, L

Material. - A single specimen, NMW2014.5G.16, unit 11, Gerdu 1 section, Kuh-e-Saluk Mountains, Kopet-Dagh.

Description. - This specimen comprises a body-chamber $32 \mathrm{~mm}$ long increasing in diameter from 12.5 to $13.3 \mathrm{~mm}$ over a distance of $17 \mathrm{~mm}$ indicating an apical angle of $3^{\circ}$. 

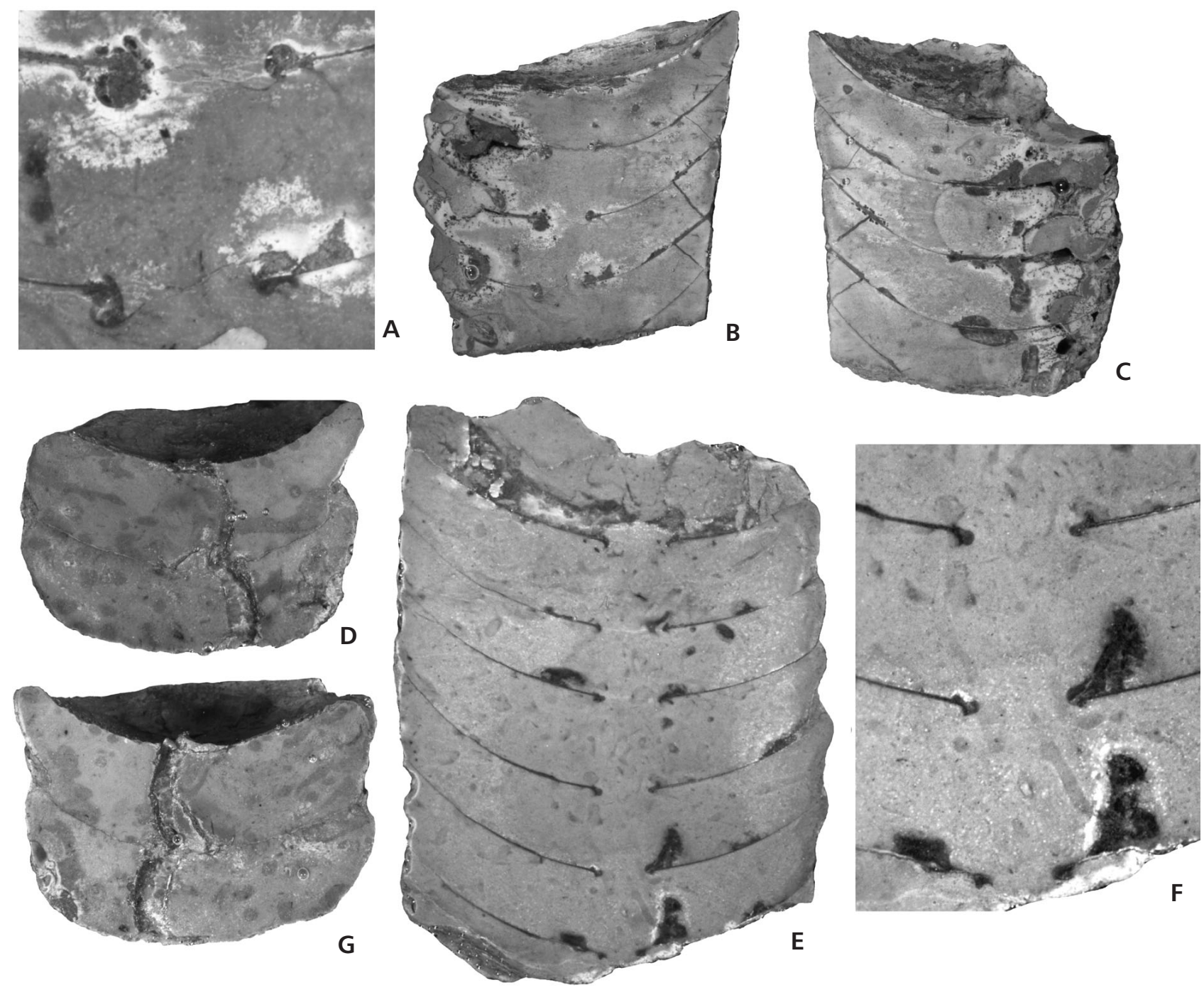

Figure 17. Cephalopods from the Qarebil Limestone Formation. • A-F-Sactoceras? sp. • A, B, C-NMW2014.5G.22, unit U7, Gerdu Valley section 2. - A - detail of siphuncle showing annulosiphonate deposits at septal necks and remains of inflated connecting rings; $\times$ 8.0. $\bullet \mathrm{B}, \mathrm{C}-\mathrm{cut}$ and polished sections through phragmocone showing siphuncle and cameral deposits (see also Fig. 18A); × 2.0. • D, G - NMW2014.5G.17, unit B9a, Gerdu Valley section 1, cut and polished sections through phragmocone showing siphuncle with deformed connecting rings and cameral deposits developed in the vicinity of the phragmocone; $\times 2.5$. $・$ E, F - NMW2014.5G.9, unit U7, Gerdu Valley section 2. • E - cut and polished section though phragmocone showing siphuncle with traces of the connecting ring (see also Fig. 18B); $\times 2.5 . \cdot \mathrm{F}-$ detail of siphuncle showing traces of connecting ring, incipient annulosiphonate deposits and possibly, cameral deposits forming the initial portion of a circumsiphuncular ridge; $\times 8.0$.

The septum at the base of the body-chamber is $3.5 \mathrm{~mm}$ in depth giving a relative septal depth $28 \%$ that of the conch diameter. Nothing is seen of the septal foramen. The annulations are $2.6 \mathrm{~mm}$ apart and consist of relatively sharp culminations and broader, smoother interspaces. The shell sculpture consists of raised longitudinal lirae that are on average $0.2 \mathrm{~mm}$ apart and transverse striae $0.1 \mathrm{~mm}$ apart. They form a reticulate pattern in which the longitudinal lirae and the transverse striae are equally prominent.

Remarks. - Based on the nature of the annulation and conch sculpture, this specimen appears to be best placed in
Palaeodawsonocerina. No additional comment is possible without additional, better-preserved material combined with further revision of this particular group of cephalopods.

Family Sactoceratidae Troedsson, 1928

\section{Genus Sactoceras Hyatt, 1884}

Type species. - Orthoceras richteri Barrande, 1868, pl. 322, figs 1-5. From the Ludlow Series, Kopanina Formation of Bohemia, Czech Republic. 
Remarks. - Although treated as an actinocerid (Teichert 1964, Kisselev 1998) and as a junior synonym of the actinocerid genus Ormoceras Stokes (Teichert 1964), Dzik (1984) transferred the genus to the Orthocerida on the grounds that the endosiphuncular deposits consisted of annulosiphonate deposits that fused on the ventral surface of the siphuncle to form parietal deposits adapically. Nor is there evidence of the presence of actinocerid type radially divided endosiphuncular deposits or a perispatium. Frey (1995) largely endorsed Dzik's conclusions and Evans (1996, 2000) further discussed the status of the genus and assigned a number of taxa to it.

\section{Sactoceras? sp.}

Figures 14O-Q, 17A-F, 18A, B

Material. - NMW2014.5G.9, 22, unit U7, Gerdu Valley section 2. NMW2014.5G.17, unit B9a, Gerdu Valley section 1.

Description. - The two specimens from unit U7 consist of short portions of an orthoconic phragmocone each about $30 \mathrm{~mm}$ in length, of roughly the same diameter, and with an apical angle of 6 degrees. There is no evidence of the nature of the conch sculpture. The suture appears to be straight and normal to the conch axis and the depth of the septa $16 \%$ that of the diameter of the phragmocone. Cameral depth is $17 \%$ of the phragmocone diameter in NMW2014.5G.9 and $22 \%$ in NMW2014.5G.22. The centre of the septal foraminae lies $45 \%$ of the way across the phragmocone from the ventral surface, and the diameter of the septal foramen is $15 \%$ that of the diameter of the phragmocone. The connecting rings are inflated and almost spherical in shape, reaching a diameter $30 \%$ that of the phragmocone and about twice the diameter of the septal foramen. The septal necks are cyrtochoanitic and recumbent with a length of $0.36 \mathrm{~mm}$ and a width of $0.8 \mathrm{~mm}$. Endosiphuncular deposits are present in NMW2014.5G.22 and take the form of annuli at the septal foraminae that are more strongly developed on the lateral than the dorsal side of the siphuncle and grow into the adapical segment, with little or no development adorally. They are also present, but much more weakly developed in NMW2014.5G.9. Cameral deposits are similarly poorly developed in this specimen and are only evident in the form of very weakly developed episeptal deposits. In NMW2014.5G.22 the cameral deposits are well developed with thick episeptal deposits developed near the phragmocone wall on the ventral side of the conch and extending onto the mural surface of the phragmocone. Hyposeptal deposits are also present, but are more restricted in their distribution and do not extend as far toward along the conch axis as the episeptal deposits. Whilst the conch wall appears to be preserved in places on the surface of
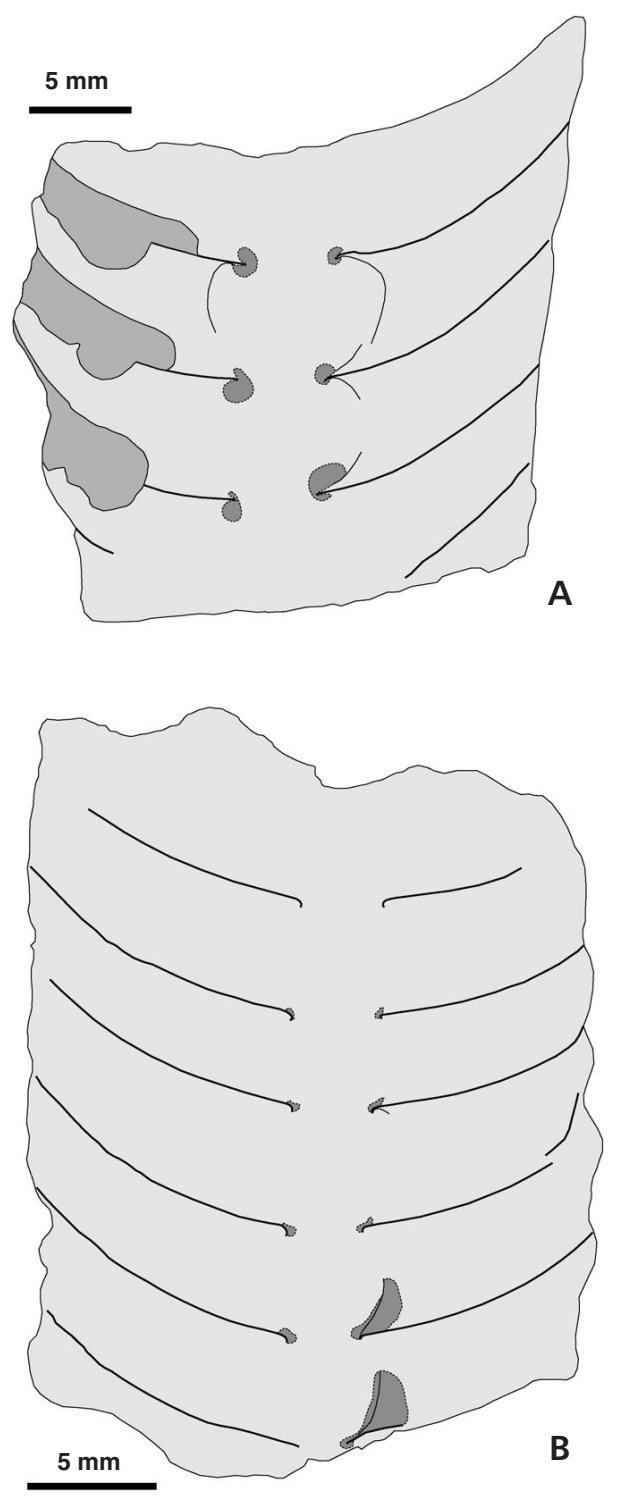

Figure 18. Interpretation of dorsoventral sagittal sections through phragmocones of specimens assigned to Sactoceras? sp. - A NMW2014.5G.22, unit U7, Gerdu Valley section 2; emphasising shape of connecting rings and distribution of endosiphuncular and cameral deposits (see also Fig. 17A, B). • B - NMW2014.5G.9, unit U7, Gerdu Valley section 2 ; picking out remaining fragments of connecting ring and partially developed circumsiphuncular ridge at the apical end of the siphuncular segment (see also Fig. 17E, F).

NMW2014.5G.22, nothing remains of any conch sculpture that might have originally been present. NMW2014.5G.17 consists of a piece of phragmocone $26 \mathrm{~mm}$ long with a diameter of $22 \mathrm{~mm}$ and cameral depth $26 \%$ that of the phragmocone diameter. The diameter of the septal foramen is about $11 \%$ that of the phragmocone diameter, whilst the relative diameter at the maximum expansion of the connecting rings reaches $25 \%$, although the siphuncular segments are slightly deformed. The septal necks are too deformed to determine their form. Within the siphuncle, there is a layer of 
crystalline material in contact with the connecting rings on the side of the phragmocone where cameral deposits are present. The fabric of the material within the siphuncle differs markedly from that of the cameral deposits, suggesting that they are not endosiphuncular deposits, but may be diagenetic in origin. The cameral deposits are largely mural and episeptal in distribution and both their profile and preserved lamellae indicate that they had a mammilate habit.

Remarks. - The fragmentary nature of this material makes it difficult to assign these specimens to Sactoceras with confidence, particularly as the conch surface is not preserved. Potentially, these specimens could also be assigned to Polygrammoceras Foerste, 1928 or Cyrtactinoceras Hyatt in Zittel, 1900, where, depending on the stage of development of the endosiphuncular deposits, it could prove difficult to distinguish these genera. In the late Wenlock Cyrtactinoceras rebelle (Barrande, 1866) from Bohemia apart from the marked curvature of the conch, the relatively marginal position of the siphuncle serves to distinguish the genus from Sactoceras. Without evidence of the nature of the conch surface, distinction from Polygrammoceras is more difficult. The paratype of Polygrammoceras bullatum (J. de C. Sowerby, 1839) from the Ludlow Series of Ledbury, Herefordshire, possesses annulosiphonate endosiphuncular deposits (Holland 2002, p. 356, pl. 1, fig. 4), as does a specimen referred to the species from the Aeronian, Goéland Member of Anticosti Island, Canada (Holland \& Copper 2008, fig. 4e). In the second specimen (NMW2014.5G.9), the annulosiphonate deposits do not appear to increase significantly in size in successive adapical segments, and may simply form discrete annuli at the septal necks throughout most of the portion of the siphuncle where they are developed. Since it is not really possible to detect any substantial change in the size of the annulosiphonate deposits in the specimen where they are best preserved (in specimen NMW2014.5G.22), the main ground for assigning these specimens to Sactoceras is that the siphuncular segments are relatively broadly inflated when compared with Polygrammoceras. Variations in the relative development of the cameral and endosiphuncular deposits may be present. Cameral deposits are developed in advance of endosiphuncular deposits in NMW2014.5G.17, and the same may be the case with NMW2014.5G.22, but the situation may be reversed in NMW2014.5G.9.

\section{Acknowledgments}

The constructive reviews provided by Štěpán Manda (Czech Geological Survey) and Andy King (Geckoella UK) have contributed to a number of improvements to the manuscript. Leonid Popov and Mansoureh Ghobadi Pour acknowledge the logistical support provided by the National Museum of Wales. The research carried out in Iran by Mansoureh Ghobadi Pour was supported by the University of Zanjan. David Evans thanks Zoe Hughes (NHMUK) for providing access to the cephalopods collected by the Oxford University Expedition to Iran.

\section{References}

AgAssiz, L. 1847. An introduction to the study of natural history, in a series of lectures delivered in the hall of the College of Physicians and Surgeons, New York. 58 pp. (fide Kummel, B. 1963. Miscellaneous nautiloid type species of Alpheus Hyatt. Bulletin of the Museum of Comparative Zoology 128, 325-368).

Ahmadzadeh-Heravi, M. 1983. Brachiopods and conodonts from the Lower Palaeozoic sediments at southern Bojnourd city. Journal of Technology and Science, Tehran University 45, 1-24. [in Persian]

BARRANDE, J. 1865-1877. Système silurien du centre de la Bohême. Part 2. Céphalopodes, texte: part 1, pp. 1-712, 1867; part 2, pp. 1-263, 1870; part 3, pp. 1-804, 1874; part 4, pp. 1-742, 1877; part 5, 1-743, 1877; supplement pp. 1-297, 1877; pls 1-107, 1865; pls 108-244, 1866; pls 245-350, 1868; pls 351-460. 1868; pls 351-460, 1870; supplement pls 461-544, 1877. Prague.

BARSKOv, I.S. 1972. Late Ordovician and Silurian molluscs of Kazahkstan and middle Asia. 109 pp. Nauka, Moscow. [in Russian]

Berry, W.B.N \& Boucot, A.J. 1970. Correlation of the North American Silurian rocks. Geological Society of America, Special Paper 102, 1-289.

Bogolepova, O.K. 1995. Lower Silurian cephalopod limestones from the Mojero River Section (Eastern Siberia, Russia) and their paleogeographic relationships. Jahrbuch der Geologischen Bundesanstalt 138, 155-160.

Brice, D., Lafuste, J., De Lapparant, A.F., Pillet, J. \& Yassini, I. 1973. Etude de deux gisements paléozoïques (Silurien et Dévonien) de l'Elbourz oriental (Iran). Annales de la Société géologique du Nord 93, 177-218.

Chen, J.Y., LiU, G. \& CHEN, T. 1981. Silurian nautiloid faunas of central and southwestern China. Memoir of the Nanjing Institute of Geology and Paleontology 13, 1-104.

Claypole, E.W. 1878. On the occurrence of a tree-like fossil plant, Glyptodendron, in the Upper Silurian (Clinton) rocks of Ohio. American Journal of Science, Series 3 15(88), 302-304. DOI 10.2475/ajs.s3-15.88.302

Cocks, L.R.M. 1979. A silicified brachiopod fauna from the Silurian of Iran. Bulletin of the British Museum (Natural History), Geology 32, 25-42.

Cuvier, G.L.C.F.D. 1797. Tableau élémentaire de l'histoire des animaux. xvi +710 pp. Deterville, Paris.

Dürkoop, A. 1970. Brachiopoden aus dem Silur, Devon und Karbon in Afghanistan. Palaeontographica, Series A 134, 153-225.

DzIK, J. 1984. Phylogeny of the Nautiloidea. Palaeontologica Polonica 45, 1-219.

Evans, D.H. 1988. Cephalopods from the Ordovician of England and Wales. 445 pp. Unpublished Ph.D. thesis, University of Wales. 
Evans, D.H. 1996. Cephalopods, 116-129. In Harper, D.A.T. \& Owen, A.W. (eds) Fossils of the Upper Ordovician. Field Guides to Fossils No. 7. 312 pp. The Palaeontological Association, London.

Evans, D.H. 2000. A cephalopod fauna from the Middle Ordovician of Saudi Arabia. Palaeontology 43, 573-589. DOI 10.1111/j.0031-0239.2000.00141.x

Evans, D.H. \& Holland, C.H. 1996. The nautiloid cephalopod Order Endocerida in the Silurian. Paläontologie Zeitschrift 69, 343-352. DOI 10.1007/BF02987799

FLOwER, R.H. 1946. Ordovician cephalopods of the Cincinnati region. Bulletin of American Paleontology 29, 1-656.

Flower, R.H. 1952. New Ordovician cephalopods from eastern North America. Journal of Paleontology 26, 24-39.

Flower, R.H. 1962. Notes of the Michelinoceratida. New Mexico Bureau of Mines and Mineral Resources, Memoir 10, 21-55.

FLOwER, R.H. 1968. Silurian cephalopods of the James Bay lowland with a revision of the Narthecoceratidae. Canadian Geological Survey, Bulletin 164, 1-88.

Flower, R.H. \& Kummel, B. 1950. A classification of the Nautiloidea. Journal of Paleontology 24, 604-616.

Flower, R.H. \& Teichert, C. 1957. The cephalopod Order Discosorida. University of Kansas Paleontological Contributions, Mollusca, Article 6, 1-114.

FoERSTE, A.F. 1893. An examination of Glyptodendron and other so-called Silurian land plants from Ohio. The American Geologist 12, 133-141.

FoERSTE, A.F. 1925. Notes on cephalopod genera, chiefly coiled Silurian forms. Denison University Bulletin, Journal of the Science Laboratory 21, 1-69.

FoERSTE, A.F. 1928. A restudy of American orthoconic Silurian cephalopods. Denison University Bulletin, Journal of the Science Laboratory 23, 236-320.

FoERste, A.F. 1936. Several New Silurian cephalopods and crinoids, chiefly from Ohio and Hudson Bay. Ohio Journal of Science 36, 261-276.

FREY, R.C. 1995. Middle and Upper Ordovician nautiloid cephalopods of the Cincinnatti Arch region of Kentucky, Indiana, and Ohio. United States Geological Survey Professional Paper 1066-P, i-iv + 1-126.

GHAVIDEL-SYooki, M. 2000. Palynostratigraphy and palaeobiogeography of lower Palaeozoic strata in the Ghelli area, Northeastern Alborz Range (Kopet-Dagh Region). Journal of Sciences, I. R. Iran 11, 305-318.

GHAVIDEL-Syooki, M. \& Vecoli, M. 2007. Latest Ordovician-early Silurian chitinozoans from the eastern Alborz Mountain Range, Kopet-Dagh region, northeastern Iran: biostratigraphy and palaeobiogeography. Reviews of Palaeobotany and Palynology 145, 173-192.

DOI 10.1016/j.revpalbo.2006.10.003

Ghobadi Pour, M., Mohibullah, M., Williams, M., Popov, L.E. \& Tolmachevae, T.Y. 2011. New, early ostracods from the Ordovician (Tremadocian) of Iran: systematic, biogeographical and palaeoecological significance. Alcheringa 35, 317-329.

GNoli, M. 1990. New evidence for faunal links between Sardinia and Bohemia in Silurian time on the basis of nautiloids. Bollettino della Società Paleontologica Italiana 29, 289-307.
GNoli, M. 2003. Northern Gondwanan Siluro-Devonian palaeogeography assessed by cephalopods. Palaeontologia Electronica 5, 1-19.

Gnoli, M. \& Serpagl, E. 1991. Nautiloid assemblages from middle-late Silurian of Southwestern Sardinia: a proposal. Bollettino della Società Paleontologica Italiana 30, 187-195.

Gnoli, M. \& Serventi, P. 2009. Silurian nautiloid cephalopods from Sardinia: the state of the art, 109-118. In CoRRADINI, C., Ferretti, A. \& ŠTorch, P. (eds) The Silurian of Sardinia. Rendiconti della Società Palaeontologica Italiana 3.

Grabau, A.W. \& SHIMER, H.W. 1910. North American index fossils: Invertebrates. Volume II. Conularida, Pteropoda, Cephalopoda, Annelida, Trilobita, Phyllopoda, Ostracoda, Cirripedia, Malacostraca, Merostomata, Arachnida, Myriopoda, Insecta, Cystoidea, Blastoidea, Crinoidea, Ophiuroidea, Asteroidea, Echinoidea and appendices. xiv + 764 pp. A.G. Seiler \& Co., New York.

Hairapetian, V., Ghobadi Pour, M., Popov, L. \& ModzaLEVSKAYA, T.L. 2012. Stegocornu and associated brachiopods from the Silurian (Llandovery) of Central Iran. Estonian Journal of Earth Sciences 61, 82-104.

DOI 10.3176/earth.2012.2.02

Hairapetian, V., Mohibullah, M., Tilley, L.J., Williams, M., Miller, C.G., Afzal, J., Ghobadi Pour, M. \& Hejazi, H. 2011. Early Silurian carbonate platform ostracods from Iran: A peri-Gondwanan fauna with strong Laurentian affinities. Gondwana Research 20, 645-653.

DOI 10.1016/j.gr.2010.12.012

HaLl, J. 1847. Descriptions of the organic remains of the lower division of the New New York system. New York Geological Survey, Palaeontology of New York. Volume 1.338 pp. C. Van Benthuysen, New York.

HALL, J. 1868. Report on the geological survey of the state of Wisconsin. Volume I. James Hall, on general geology and palaeontology, and J. D. Whitney, on the upper Mississippi lead region. $\mathrm{xx}+455 \mathrm{pp}$. Commissioners of the Geological, Mineralogical, and Agricultural Survey, Wisconsin.

Hansen, T. 2009. Trilobites from the Middle Ordovician Elnes Formation of the Oslo Region, Norway. Fossils and Strata 56, $1-215$.

Histon, K. 2012a. Paleoenvironmental and temporal significance of variably colored Paleozoic orthoconic nautiloid cephalopod accumulations. Palaeogeography, Palaeoclimatology, $\mathrm{Pa}$ laeoecology 367, 193-208.

DOI 10.1016/j.palaeo.2012.07.008

Histon, K. 2012b. The Silurian nautiloid-bearing strata of the Cellon Section (Carnic Alps, Austria): Color variation related to events. Palaeogeography, Palaeoclimatology, Palaeoecology 367, 231-255. DOI 10.1016/j.palaeo.2012.10.012

Histon, K. 2012c. An Alpine immigrant: Phragmoceras Broderip, 1839 from the Silurian of the Carnic Alps. Geobios 45, 41-48. DOI 10.1016/j.geobios.2011.11.009

Holland, C.H. 2002. One of many problems: Taxonomy of the common Silurian nautiloid cephalopod "Orthoceras" bullatum J. de C. Sowerby. Abhandlungen der Geologischen Bundesanstalt 57, 353-358.

Holland, C.H. 2014. Biostratigraphy of British Silurian nautiloid cephalopods. Bollettino della Società Paleontologica Italiana 53, 19-26. DOI 10.4435/BSPI.2014.02 
Holland, C.H \& Copper, P. 2008. Ordovician and Silurian nautiloid cephalopods from Anticosti Island: traject across the Ordovician-Silurian $(\mathrm{O}-\mathrm{S})$ mass extinction boundary. Canadian Journal of Earth Sciences 45, 1015-1038. DOI 10.1139/E08-048

Holland, C.H. \& STRIDSBerg, S. 2004. Specific representation of the Silurian cephalopod genus Phragmoceras in Gotland and Britain. GFF 126, 301-310. DOI 10.1080/11035890401263301

Hyatt, A. 1883-1884. Genera of fossil cephalopods. Proceedings of the Boston Society for Natural History 22, 253-272 (1883), 273-338 (1884).

JiLSON, W.R. 1931. The Paleontology of Kentucky. xi + 463 pp. Kentucky Geological Survey, Frankfort, Kentucky.

JiN, J. \& COPPER, P. 2000. Late Ordovician and Early Silurian pentamerid brachiopods from Anticosti Island, Québec, Canada. Palaeontographica Canadiana 18, 1-140.

Kisselev, G.N. 1998. Silurian cephalopods of northern Siberia. 94 pp. St Petersburg University.

Kozlu, H., Sachanski, V. \& Göncüoglu, M.C. 2012. Silurian, 61-78. In Göncüoglu, M.C. \& Bozdogan, N. (eds) Guidebook to Palaeozoic of eastern Taurides. Turkish Association of Petroleum Geologists, Special Publication 7.

KRÖGER, B. 2008. Nautilids before and during the origin of ammonoids in a Siluro-Devonian section in the Tafilalt, AntiAtlas, Morocco. Special Papers in Palaeontology 79, 1-110.

KRÖGER, B. 2013. The cephalopods of the Boda Limestone, Late Ordovician, of Dalarna, Sweden. European Journal of Taxonomy 41, 1-110. DOI 10.5852/ejt.2013.41

KRÖGER, B. \& IsAKAR, M. 2006. Revision of annulated orthoceridan cephalopods of the Baltoscandic Ordovician. Fossil Record 9, 137-163. DOI 10.1002/mmng.200600005

KröGER, B., Zhang, Y. \& IsAKar, M. 2009. Discosorids and Oncocerids (Cephalopoda) of the Middle Ordovician Kunda and Aseri Regional Stages of Baltoscandia and the early evolution of these groups. Geobios 42, 273-292. DOI 10.1016/j.geobios.2008.09.006

Kunn, O. 1940. Paläozoologie in Tabellen. 50 pp. G. Fischer, Jena.

MANDA, Š. 2007. New Silurian nautiloids Phragmoceras Broderip, 1839, and Tubiferoceras Hedström, 1917, from the Prague Basin (Bohemia). Bulletin of Geosciences 82(2), 119-131. DOI 10.3140/bull.geosci.2007.02.119

MANDA, Š. 2008. Palaeoecology and palaeogeographic relations of the Silurian phragmoceratids (Nautiloidea, Cephalopoda) of the Prague Basin (Bohemia). Bulletin of Geosciences 83(1), 39-62. DOI 10.3140/bull.geosci.2008.01.039

MANDA, Š. \& KŘižz, J. 2007. New cephalopod limestone horizon in the Ludlow (Gorstian, lower L. scanicus Biozone) of the Prague Basin (Bohemia, Perunica). Bollettino della Società Paleontologica Italiana 46, 33-45.

Manda, ك̌. \& TureK, V. 2009. Minute Silurian oncocerid nautiloids with unusual colour patterns. Acta Palaeontologica Polonica 54, 503-512. DOI 10.4202/app.2008.0062.

Marek, J. 1999. Ordovician cephalopods of the Prague Basin (Barrandian area, Czech Republic): a review. Acta Universitatis Carolinae, Geologica 43, 413-416.

McCoy, F. 1844. A synopsis of the characters of the Carboniferous Limestone fossils of Ireland. 274 pp. Dublin University Press, Dublin. DOI 10.5962/bhl.title.11559
Miagkova, E.I. 1967. Silurian nautiloids of the Siberian platform. 47 pp. Nauka, Moscow. [in Russian]

Mutvei, H. 1957. On the relationship of the principal muscles to the shell in Nautilus and other fossil nautiloids. Arkiv för Mineralogi och Geologi 2, 219-254.

Mutvei, H. 2012. Siphuncular structure in Silurian discosorid and ascocerid nautiloids (Cephalopoda) from Gotland, Sweden: implications for interpretation of mode of life and phylogeny. GFF 134, 27-37. DOI 10.1080/11035897.2012.654507

Niко, S. \& Hamada, T. 1989. Silurian Orthocerataceaea (Mollusca: Cephalopoda) from the Yokokurayama Formation, Kurosegawa Terrane. Transactions and Proceedings of the Palaeontological Society of Japan, New Series 154, 59-67.

Niko, S., Kakuva, Y., Watanabe, D. \& Matsumoto, R. 1999. Early Silurian actinoceratid and orthoceratid cephalopods from the Kerman area, East-Central Iran. Palaeontological Research 3, 41-48.

Niko, S., Masatoshi, S. \& Leman, M. S. 2007. Two new species of orthocerid cephalopod from the Carboniferous, Panching Limestone, West Malaysia. Paleontological Research 11, 331-336. DOI 10.2517/1342-8144(2007)11[331:TNSOOC]2.0.CO;2

Page, A.A., Zalasiewicz, J.A., Williams, M. \& Popov, L.E. 2007. Were transgressive black shales a negative feedback modulating glacioeustacy in the Early Palaeozoic icehouse?, 125-156. In Williams, M., Haywood, A.M., Gregory, F.J. \& Schmid, D.N. (eds) Deep-time perspectives on climate change: marrying the signal from computer models and biological proxies. The Micropalaeontological Society, Special Publications. i-vi +589 pp. The Geological Society, London.

Popov, L.E. \& Cocks, L.R.M. 2013. The radiation of early Silurian spiriferide brachiopods, with new taxa from the Llandovery of Iran. Alcheringa 37, 558-564.

DOI 10.1080/03115518.2013.828254

Popov, L.E., Ghobadi Pour, M., Bassett, M.G. \& Kebria-Ee, M. 2009. Billengsellidae and orthide brachiopods: new insights into earliest Ordovician evolution and biogeography from northern Iran. Palaeontology 52, 35-52. DOI 10.1111/j.1475-4983.2008.00833.x

Rong, J. \& CHEN, X. 2003. Silurian biostratigraphy of China, 173-234. In Zhang, W.T., Chen, P.J. \& Palmer, A.R. (eds) The Biostratigraphy of China. i-iii +599 pp. Science Press, Beijing.

RonG, J., XU, H. \& YANG, X. 1974. Silurian brachiopods, 195-208. In NANJing Institute of GeOlogy and Palaeontology, Academia Sinica (ed.) The Handbook of Stratigraphy and Palaeontology in Southwest China. Science Press, Beijing. [in Chinese]

Serpagli, E. \& Gnoli, M. 1977. Upper Silurian cephalopods from southwestern Sardinia. Bollettino della Società Paleontologica Italiana 16, 155-196.

Sowerby, J. DE C. 1839. Shells, 589-712. In MurChison, R.I. The Silurian System. 768 pp. John Murray, London.

Strand, T. 1934. The Upper Ordovician cephalopods of the Oslo area. Norsk Geologisk Tidsskrift 14, 1-117.

SUNDQUIST, B. 1982. Wackestone petrography and bipolar orientation of cephalopods as indicators of littoral sedimentation in the Ludlovian of Gotland. GFF 104, 81-90. 
SutTner, T.J. \& KRÖGER, B. 2006. Late Ordovician to early Silurian Gondwanan cephalopods of the Pin Formation (Spiti, northern India). Neues Jahrbuch für Geologie und Paläontologie, Monatshefte 2006(10), 595-612.

SweEt, W.C. 1958. The Middle Ordovician of the Oslo Region, Norway. 10. Nautiloid cephalopods. Norsk Geologisk Tidsskrift 38, 1-176.

SweEt, W.C. 1959. Ordovician and Silurian Cyrtogomphoceratidae (Nautiloidea) from the Oslo region, Norway. Journal of Paleontology 33, 55-62.

SweEt, W.C. 1964a. Orthocerida, K216-K261. In Moore, R.C. (ed.) Treatise on invertebrate paleontology. Part K. Mollusca 3, Cephalopoda. General features, Endoceratoidea, Actinoceratoidea, Nautiloidea, Bactritoidea. xxxvii + 519 pp. Geological Society of America \& University of Kansas Press, Boulder \& Lawrence.

Sweet, W.C. 1964b. Oncocerida, K277-K319. In Moore, R.C. (ed.) Treatise on invertebrate paleontology. Part K. Mollusca 3, Cephalopoda. General features, Endoceratoidea, Actinoceratoidea, Nautiloidea, Bactritoidea. xxxvii + 519 pp. Geological Society of America \& University of Kansas Press, Boulder \& Lawrence.

Teichert, C. 1930. Die Cephalopoden-Fauna der LyckholmStufe des Ostbaltikums. Paläontologische Zeitschrift 12, 264-312. DOI 10.1007/BF03044452

Teichert, C. 1964. Actinocerida, K190-K216. In Moore, R.C. (ed.) Treatise on invertebrate paleontology. Part K. Mollusca 3, Cephalopoda. General features, Endoceratoidea, Actinoceratoidea, Nautiloidea, Bactritoidea. xxxvii +519 pp. Geological Society of America \& University of Kansas Press, Boulder \& Lawrence.

ToRsviK, T.H. \& Cocks, L.R.M. 2013. New global palaeogeo- graphical reconstructions for the Early Palaeozoic and their generation, 2-24. In HARPER, D.A.T. \& SERVAIS, T. (eds) Early Palaeozoic Biogeography and Palaeogeography. Geological Society of London, Memoir 38. DOI 10.1144/M38.2

Torsvik, T.H., Van der Voo, R., Preeden, U., Mac Niocaill, C., Steingerger, B., Doubrovine, P.V., van Hinsbergen, D.J.J., Domeier, M., Gaina, C., Tohver, E., Meert, J.G., McCausLAND, P.J.A. \& Cocks, L.R.M. 2012. Phanerozoic polar wander, palaeogeography and dynamics. Earth Science Reviews 114, 325-368. DOI 10.1016/j.earscirev.2012.06.007

Troedsson, G.T. 1928. On the Middle and Upper Ordovician faunas of northern Greenland, 1. Cephalopods. Meddelelser om Grønland 71, 1-157.

Troedsson, G.T. 1932. Studies on Baltic fossil cephalopods, II. Vertically striated or fluted orthoceracones in the Orthoceras limestone. Lunds Universitets Arsskrift 28, 1-38.

TuREK, V. 2008. Boionautilus gen. nov. from the Silurian of Europe and North Africa (Nautiloidea, Tarphycerida). Bulletin of Geosciences 83(2), 141-152.

DOI 10.3140/bull.geosci.2008.02.141

Wolfart, R., Bender, F. \& Stein, V. 1968. Stratigraphie und Fauna des Ober-Ordoviziums (Caradoc-Ashgill) and UnterSilurs (Unter-Llandovery) von Sudjordanien. Geologisches Jahrbuch, Beihefte 85, 517-551.

Zhuravleva, F.A. 1959. O semeistve Pseudorthoceratidae Flower \& Caster, 1935. Akademia nauk SSSR, Doklady 116, 677-680. [in Russian]

Zhuravleva, F.A. 1964. New Ordovician and Silurian cephalopods from the Siberian platform. Paleontological Journal 1964, 87-100.

ZitTel, K.A. von 1900. Text-book of palaeontology. Volume 1. 706 pp. Macmillan, London \& New York. 